\title{
Archaeological History of a Fijian Island: Moturiki, Lomaiviti Group
}

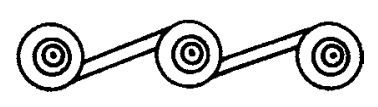

\author{
MARÍA CRUZ BERROCAL, ANTONIO URIARTE GONZÁLEZ, \\ SIDSEL MILLERSTROM, SUSANA CONSUEGRA RODRÍGUEZ, \\ JUANA PÉREZ-ARIAS, AND SANTIAGO ORMEÑO
}

\section{INTRODUCTION}

In 2007, we STARTed a PROJeCt to ReCORd ROCK ART in Fiji (Cruz Berrocal and Millerstrom 2013; Millerstrom and Cruz Berrocal 2009, 2010), focusing in 2008 on a site called Vatu Vola that had been discovered in 2006 in the Naisogorourou area on Moturiki (pers. comm. Jone Balenaivalu, 13 September 2007). We designed our fieldwork there as a selective survey to understand the mechanisms of landscape construction associated with the making of rock art on small islands. The survey and further archaeological explorations of Moturiki rendered significant data and raised research questions presented in this article (Cruz Berrocal and Millerstrom 2013).

Moturiki is one of the islands in the Lomaiviti group in central Fiji. The island's surface is 1473 ha, including 1130 ha of mainland and 343 ha of mangrove (calculations based on the cartographic base listed below). It is a volcanic outlier of Ovalau (Fig. 1). As a high island with maximum altitudes around $120 \mathrm{~m}(116 \mathrm{~m}$ according to the Digital Terrain Model of the island; source GDEM, below), it has a diversified landscape and, especially in the south, the topography is remarkable (Fig. 2). This setting provides different landscape contexts for archaeological inquiry. In addition, Moturiki has one of the oldest Lapita settlements (including a burial) found so far in Fiji (Nunn et al. 2007), thus one of a limited number of sites with Lapita remains that can be analyzed (Petchey et al. 2011:30). The island therefore provides evidence for the entire sequence of Fijian prehistory, from the earliest Lapita settlement, through European contact, up to the present.

Moturiki appears to be interrelated with other islands in the Lomaiviti group, such as Ovalau, Yanuca Levu, Caqalai, and Leleuvia, thus creating the opportunity to study the islands as single entities or as part of an extended social and historical network.

Dr. María Cruz Berrocal is a Research Fellow affiliated with Zukunftskolleg, University of Konstanz, Konstanz, Germany. Antonio Uriarte González is a Senior Technician at the Laboratory of Remote Sensing and Landscape Archaeology, Instituto de Historia, CCHS, CSIC, Madrid, Spain. Dr. Sidsel Millerstrom is a researcher affiliated with the Oceanic Archaeology Laboratory, ARF, University of California at Berkeley. Susana Consuegra Rodríguez is a researcher affiliated with the Instituto de Historia, CCHS, CSIC, Madrid, Spain. Dr. Juana Pérez-Arias is a Professor at the Universidad Politécnica, Madrid, Spain. Dr. Santiago Ormeño is a Professor at the Universidad Politécnica, Madrid, Spain. 


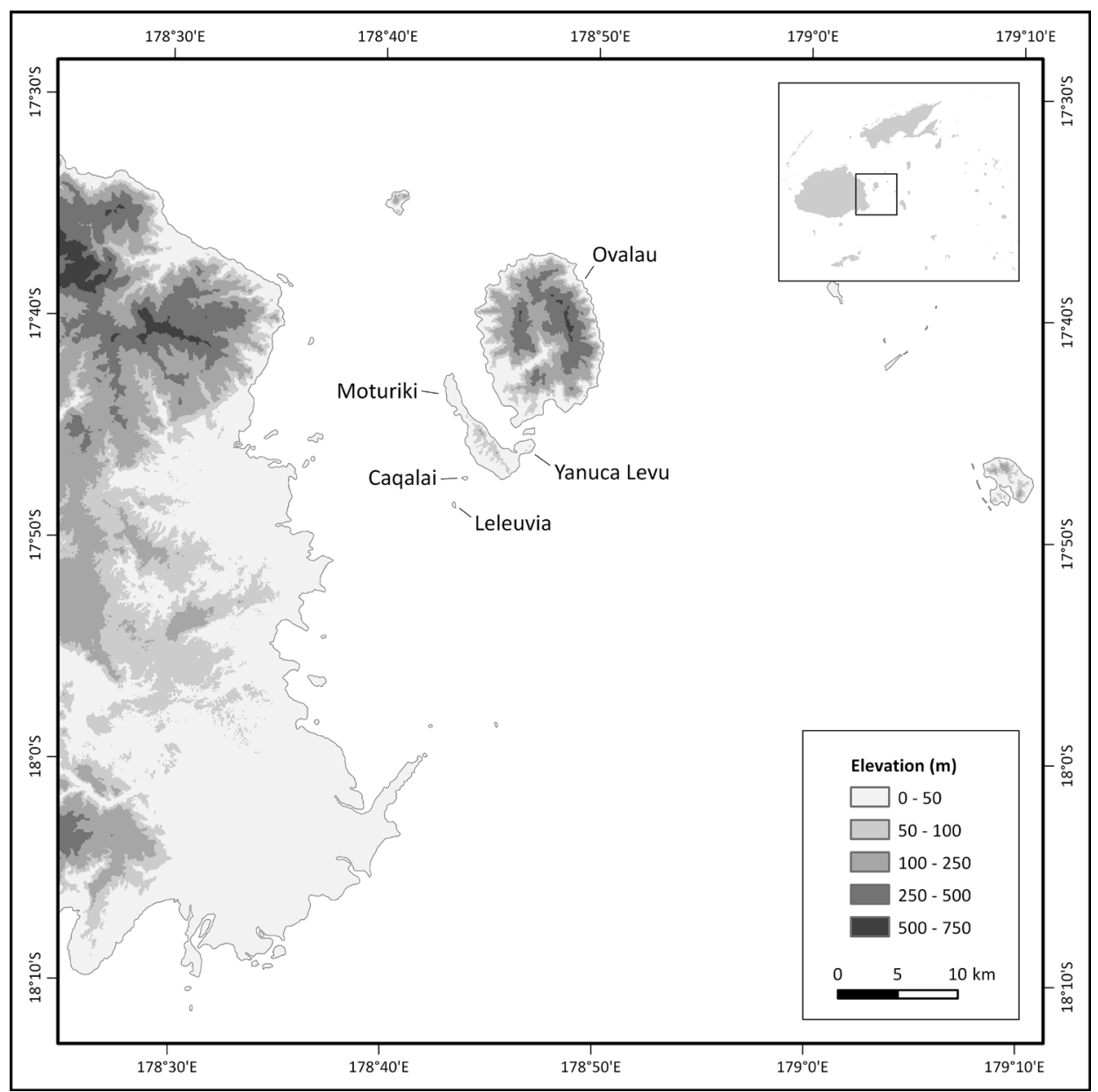

Fig. 1. Lomaiviti group, Fiji.

Ovalau and Moturiki, within the Lomaiviti context, are a small-scale model of the Fijian archipelago in that they are distinct islands but clearly belong to a wider network and seem to exhibit the most prominent and essential features of large islands. They can therefore be considered something of a "proxy" for the region. Most importantly, the Lomaiviti group lies between and is influenced by Lau (with its Tongan heritage) on one side and the rest of Fiji on the other; the whole of Fiji has been considered an "in-between" archipelago (Kirch 2000:155). In short, Moturiki provides a field laboratory for archaeologically testing the potential mixing of traditions, in line with research on other "transitional" areas in other parts of Fiji (Sand et al. 2007).

An important amount of archaeological research provides a solid foundation for our work. Surveys have been developed in Lakeba (Best 1984) and Naqelelevu (Sand et al. 2007). Many studies have been devoted to the analysis and revision pottery sequences in Fiji (Best 1984; Birks 1973; Burley 2002; Frost 1979; Green 1963; Sand et al. 2007; Shaw 1967). Researchers have focused on settlements and agricultural infrastructures in Fijian prehistory (Field 2004) and marine resource exploitation, 


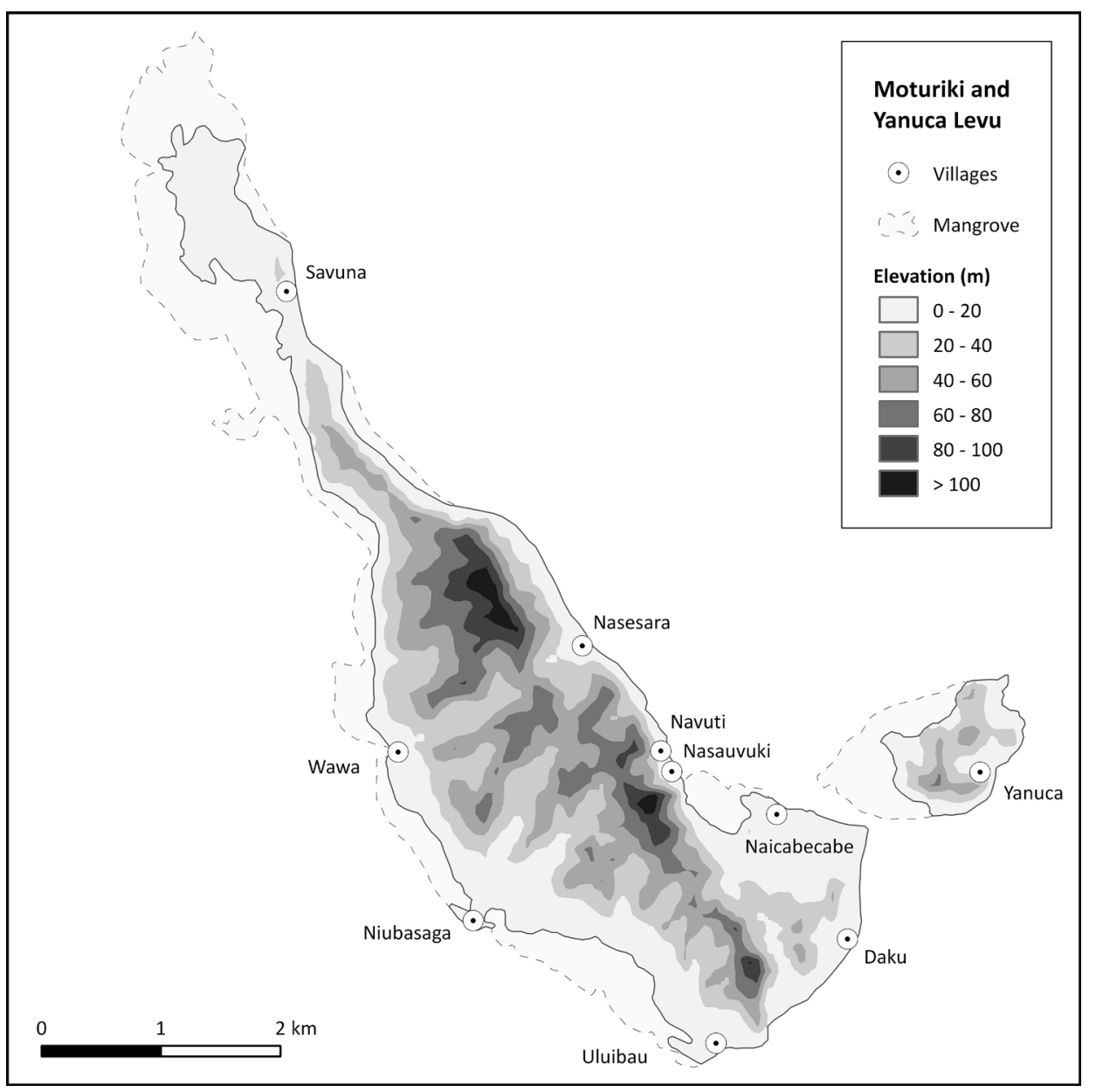

Fig. 2. Moturiki and Yanuca Levu islands.

ethnoarchaeology, and zooarchaeology (Jones 2009a, 2009b). These studies provide a preliminary basis for interpreting archaeological evidence in Moturiki. Furthermore, previous archaeological work by Nunn and colleagues (2007) in Moturiki can be compared with our data to explore topics such as settlement pattern and environmental change.

This article further develops our preliminary findings (Cruz Berrocal et al. 2011). We present our methodology in the field and in the laboratory, discuss our results, and point out questions that arose from our research.

\section{SURVEY METHODOLOGY}

Our survey was carried out in 2008 by María Cruz Berrocal and Sidsel Millerstrom and in 2010 by Cruz Berrocal, Antonio Uriarte González, and Juan Gaspar Leal Valladares on Moturiki and Yanuca and the atolls of Caqalai and Leleuvia. The land- 
scape of Moturiki and Yanuca Levu imposed a series of constraints on survey design and execution. Landscape factors included:

1. Impregnable or dense vegetation, typical of tropical rain forest, covers most of the island. This comprises different types of formations (woodland, shrub, creeping plants, pastures) depending on successive stages of human-induced clearing and subsequent regeneration.

2. Rugged terrain, with steep slopes, in the inland hills.

3. Swampy terrain on much of the coastal lowlands area.

4. Slash-and-burn agriculture practiced in the inland hills, which clears vegetation cover and exposes the soil.

These conditioning factors put the following limitations on our archaeological survey:

1. Low archaeological visibility in areas with dense vegetation or swampy soil. On the other hand, slash-and-burn agriculture has the opposite effect, creating plots that are archaeological windows for soil inspection.

2. Displacement of archaeological items (mainly pottery fragments and shells) due to strong erosion-deposition processes on the steep slopes increased by slash-andburn practices.

3. Difficulties for the movement of surveyors due to vegetation, rugged terrain, and swamps.

Because of these limitations, we opted for a selective strategy, choosing a series of target places to survey. This was not a fragmentary or arbitrary strategy. Our objective was to obtain a representative portrait of the distribution of the archaeological record by investigating as many areas as possible across the different types of landscape found over the entire island. In order to facilitate this objective, we superimposed an orthogonal grid formed of $250 \times 250 \mathrm{~m}^{2}$ squares on the island map. We used this grid as a template for monitoring surveyed and unsurveyed areas (Fig. 3). Matching the coastal profile of Moturiki and Yanuca Levu (excluding the mangrove areas mentioned above) against this square grid provided the following figures: 11,303,549 $\mathrm{m}^{2}$ for Moturiki, and 799,643 $\mathrm{m}^{2}$ for Yanuca. We considered "surveyed squares" any that included at least a GPS measurement. A total of 5,138,095 $\mathrm{m}^{2}(45.5 \%)$ were covered by survey in Moturiki and 161,595 $\mathrm{m}^{2}(20.2 \%)$ in Yanuca. Caqalai and Leleuvia were surveyed in their entirety.

For planning the survey and gathering and managing fieldwork data, we implemented a spatial database using a combination of Database Management System (DBMS) and Geographical Information System (GIS) software (Microsoft Access and ESRI ArcGIS). Additional geographical layers were included with the aim of contextualizing archaeological features within their landscape setting:

1. Topographic Map 1:50,000 (Fiji Map Series 31), specifically sheets 027 (Korovou) and P27 (Ovalau), both edited in 1993, digitized and georeferenced. ${ }^{1}$

2. Advanced Spaceborne Thermal Emission and Reflection Radiometer (ASTER) Global Digital Elevation Model (GDEM). ${ }^{2}$

3. High-resolution satellite imagery, specifically two QuickBird images, acquired 15 August 2005 and 19 October 2007.3

4. Moturiki Island Coconut Plantation and Land Classification Map, digitized and georeferenced. ${ }^{4}$ 


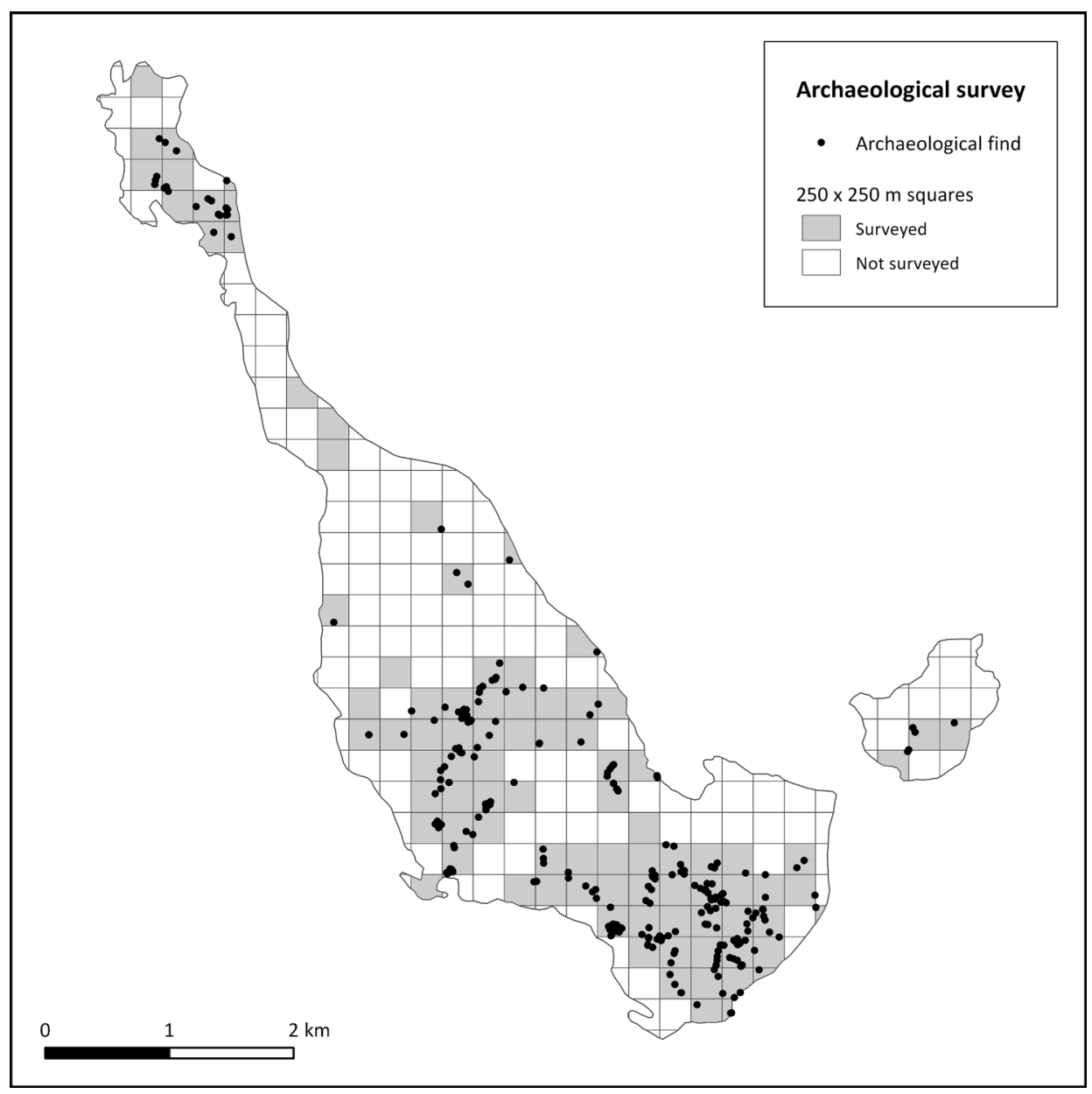

Fig. 3. Surveyed areas in Moturiki and Yanuca Levu.

5. Map 1:20,000 showing distribution of Mataqali (Fijian kinship groups), digitized and georeferenced..$^{5}$

We planned a survey agenda for each day, establishing places to inspect and routes to reach them. Survey locations were selected using (and usually combining) the following criteria:

1. Information provided by local people, especially field guides, about the presence of archaeological remains in a certain area. In many cases there is a narrative associated with the site. Although oral history may be an important source of information, we could not assume that oral accounts had a centenary or millenary life. Local people had apparently done exactly what we tried to do: noticing the remains and making sense of them. In this way, oral accounts would be a posteriori interpretations, not necessarily an independent line of evidence. ${ }^{6}$ In our opinion, oral history may be a means to approach some big issues, rather than fine-grained 
details at the level of the site (see also Lilley et al. 2012). ${ }^{7}$ In the case of Moturiki, oral history seems to acknowledge significant influence from Tonga, as well as traveling and exchange among islands. ${ }^{8}$

2. Geographical features, based on structural characteristics of landscape as topography, land use, and so on (e.g., ridges, valleys). We did not only define those areas suitable for survey, but also discarded those impossible to survey due to null visibility or impassable terrain (e.g., swamps).

3. Visual interpretation of satellite imagery, selecting features that seemed archaeological (e.g., terraces), for subsequent survey. Results are still limited, but the potential of satellite imagery to work in heavily vegetated areas and archipelagos with complex logistic problems is important. Above all, given some initial knowledge of an island, satellite imagery can greatly improve researchers' ability to predict likely locations of archaeological findings.

Finally, we registered occasional finds during our walks to the target places. This opportunistic practice notably enriched the final results, filled many gaps in the data, and provided a more complete image of the distribution of the archaeological record across Moturiki.

Given the usefulness of such chance finds, we recorded the paths we followed in order to factor in these areas of terrain in our calculations of the walked areas and recorded the kind of vegetation we encountered. This enabled us to assess if archaeological voids were due to scarce visibility on the ground or to lack of survey. Data were entered into the computer daily to check visited areas and still-existing voids. This daily examination of field data allowed us to test the results of our strategies and confirm or modify them as appropriate.

The selection criteria discussed above were applied differently during the two field seasons. In 2008, we were primarily interested in documenting likely areas for the occurrence of rock art sites (i.e., lowlands, water sources, narrow ridges), which was our initial motivation for undertaking research on Moturiki. We also surveyed the interior of the island, relying primarily, because of time constraints, on the extensive knowledge of our field guide, Sitiveni Namua (Siti) and references from other local people. ${ }^{9}$ We recorded all archaeological remains known to our informants. Siti also shared oral accounts related to the sites we visited. ${ }^{10}$

This opportunistic method enabled us to document 44 previously unknown archaeological sites on Moturiki, in addition to undocumented sites on Yanuca Levu, Caqalai, and Leleuvia. This field season prepared us to take a more systematic approach in 2010. During this second season, we implemented all of the criteria specified above in order to fill in gaps in our previous survey. Sources of geographical information played the main role in 2010. Visited places included those recorded in 2008, although after some initial trials we did not rerecord features since it did not significantly add to our previous documentation.

\section{DATA RECORDING AND ANALYSIS}

Field survey was primarily directed toward documenting archaeological items, but we also recorded other data, including areas where there were no findings, photographic positions, ethnographic and geographic features (currently used areas such as 
cemeteries, cultivated plots, water sources, etc.), and vegetation formations. Our field observations related to a variety of elements, and were classified as either archaeological or methodological observations to be processed in the lab.

Documentation of archaeological findings involved three main tasks: (1) georeferencing of archaeological features using GPS; (2) textual descriptions of findings through the use of specifically designed forms; and (3) photographic recording of and from the sites. In spite of some difficulty obtaining a good signal in forested areas, most GPS measurements were accurate enough, with deviations under $0.5 \mathrm{~m}$, thanks to the equipment used and the application of differential correction (DGPS) in the lab. ${ }^{11}$

All fieldwork information was added to the abovementioned spatial database to be combined with the geographical layers and mapped. Field data were grouped into two types of archaeological features to produce a more synthetic view: (1) structures, defined as evidence of human-built features (such as terraces, ditches, and house mounds or yavus) that, regardless of their state of preservation, are in situ; and (2) scatters, defined as relatively wide sets of dispersed artifact fragments (mainly pottery and shell). We paid special attention to ceramics because of their potential diagnostic chronocultural character. Scatters are evidently displaced from their original archaeological deposit, often quite far, as in the case of those located on slopes and lowlands whose fragments came from upper locations. We recorded surface pottery even when it was clearly out of place.

\section{Structures}

We used the following criteria in order to cluster field observations into structures:

1. Internal consistency of structures, forming closed sites. This is the case of ringditch villages, where a circular ditch forms an enclosed and discrete settlement.

2. Topography, based on the presence of archaeological structures on a landform, usually a ridge or channel. ${ }^{12}$ This criterion was quite useful for grouping terrainconditioning structures (terraces and house mounds), since most of them were located on ridges.

3. Spatial proximity of the structures.

An extended discussion about the criteria we used to individualize or aggregate field observations in each case is omitted here. However, we would like to point out that some of the types we defined are more problematic than others. Specifically terraces/house mounds, and isolated yavus tend to form a continuous archaeological landscape; therefore, field observations may not suffice to individualize them. Later analysis in the laboratory allowed us to make decisions as to their materiality. Thus, the high village sites that we call terraces/house mounds are very complex archaeological phenomena. Terraces, house mounds, lookouts, and even defensive structures have been recorded at such sites. Ring-ditch villages, on the other hand, are more easily delimited and therefore apt for making comparisons (see below).

\section{Scatters}

The dispersion of surface material tends to be large due to particularly aggressive rains or other factors, and secondary pottery scatters are sometimes not necessarily obvious in the field. On many occasions, it was impossible to locate the likely place of origin 
of the pottery scatter because of visibility issues. We therefore double-checked the extrapolated positions of every site so as not to introduce large errors. We preferred not to reconstruct likely places of origin of the pottery in secondary deposition, but instead showed secondary scatters as dispersions mapped through the application of the following topographical criteria:

1. Scatters were assigned to already-defined sites — formed by structures - if they lay within their bounds (e.g., ring-ditch villages), were in close spatial proximity, or were located on the same ridge.

2. Scatters were not associated with any site if they were plausibly in a secondary position, far away from any structure, and located on depositional areas (downslope or at the bottom of valleys). They presumably originated in the ridges above, however.

Mapping the scatters procured an approximation of the extent to which the archaeological record has been affected by post-depositional processes. As discussed below, much of the secondary depositions of pottery are in the lowlands.

\section{RESULTS}

We tentatively classified sites based on the work of Best (1984:45) and our own observations, using size and presence/absence of key elements such as terraces, house mounds, ring ditches, defensive earthworks, graves, or rock art as main criteria. Settlement appears to be structured into two basic types: ring-ditch villages, and occupation areas formed by terraces and house mounds. The rest of the sites appear to be isolated house mounds, burial places (including contemporary and historic sites, recognizable through their use of vatuvuso or coral blocks, also found on yavus), water sources (generally wells and natural springs located on the lowlands and coastal plains), and some historical remains such as the locally known Cakobau's house, a heavily disturbed rectangular structure. We also recorded a rock art site and a boulder with grinding marks (Cruz Berrocal and Millerstrom 2013).

Following the data analysis procedure discussed above, we defined 89 sites (including structures and pottery scatters) from 498 archaeological recordings in the field, which gives an idea of the intensity of the survey. The 89 sites include 86 in Moturiki and 1 in Yanuca Levu; each of the Caqalai and Leleuvia atolls can be defined as one archaeological site (Fig. 4, Table 1). Most of the archaeological sites found during the survey are located in the hilly southern part of Moturiki.

We focus here on a general evaluation of the location of sites throughout Moturiki, paying attention to topographic features. As pointed out above, there is a notable difference in the number of sites between the northern and southern parts of Moturiki. The hilly southern area has always been more populated than the dry, flat northern area. It is also more extensive: disregarding the isthmus between the areas, the surface of the northern area is only 91 ha, while the southern part accounts for 995 ha of the island, respectively 8.4 percent and 91.6 percent of the land surface. The current population lives in one village in the northern area and eight villages in the south (11.1\% and $88.9 \%$ of the total number of villages, respectively).

The main types of archaeological sites also follow this pattern: (1) ring-ditch villages include one village to the north and nine to the south $(10 \%$ and $90 \%$, respectively); (2) villages include one village to the north and seventeen to the south 


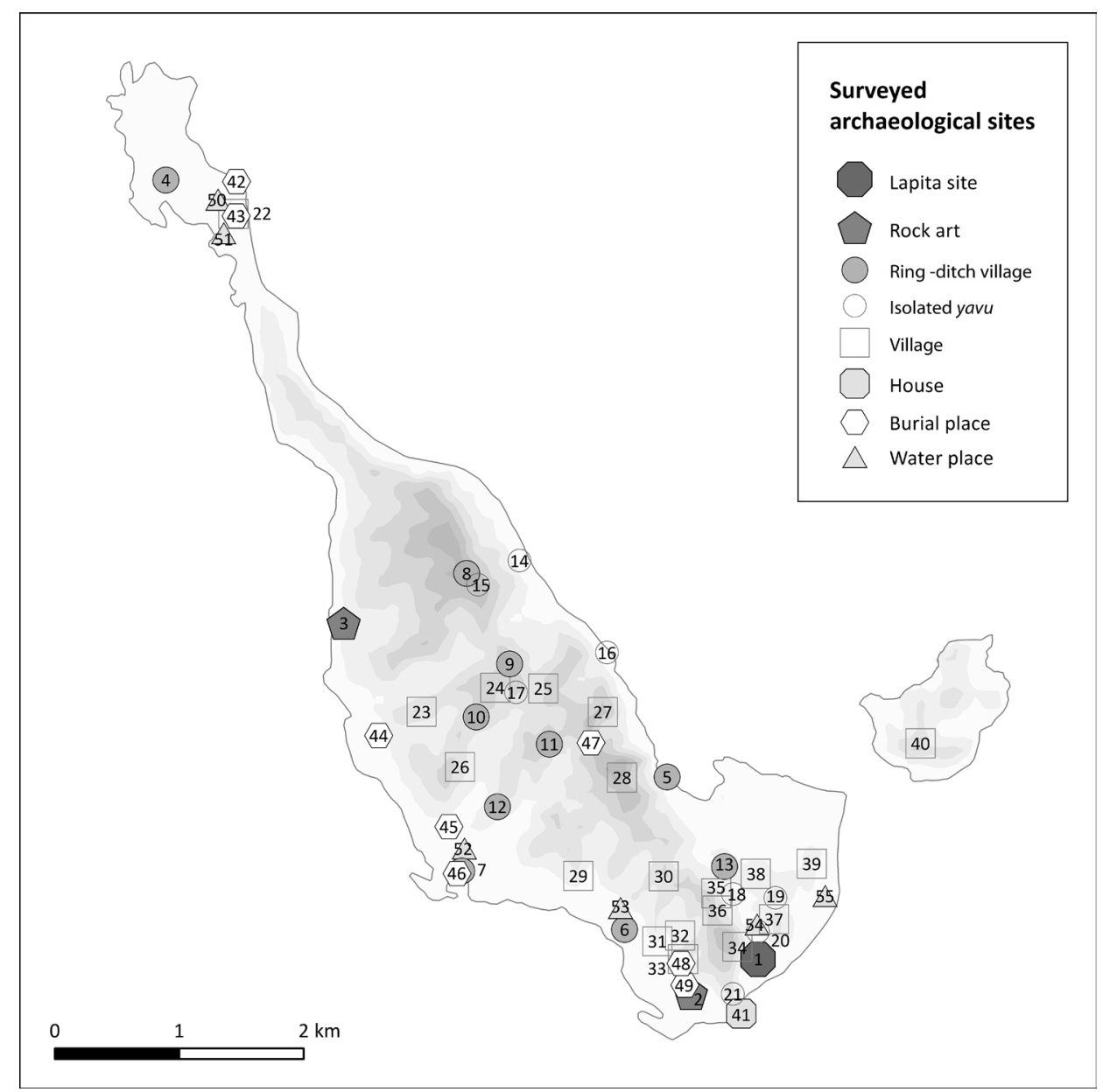

Fig. 4. Archaeological sites surveyed in Moturiki and Yanuca Levu. Lapita site: 1. Naitabale / Seremaia. Rock art: 2. Vatu Vola (Naisogorourou); 3. Menawai. Ring-ditch villages: 4. Old Savuna; 5. Nasara; 6. Korolevu; 7. Korovou; 8. Soso; 9. Nawaqa; 10. Moturiki; 11. Koronisici; 12. Mataniwai; 13. Sawaikede. Isolated yavus: 14. Laqiniwasa; 15. Nabureni; 16. Old Navuti; 17. Tabutabu; 18. Babadamu; 19. Nacuvodu; 20. Naitarakucu mound; 21. Kamunagauluna. Villages (terraces / house mounds): 22. Old Savuna; 23. Mataitova; 24. Kororua / Navico; 25. Namuka; 26. Korogele; 27. Nasiriva; 28. Navitiro / Delanikoro; 29. Ucuibulu; 30. Naselesele; 31. Daivetalevu; 32. Dalodalo / Na Ovo Ovo; 33. Deleinagaga / Delainawaqaibonu; 34. Korovatu; 35. Nabuavesi 1; 36. Nabuavesi 2; 37. Qaravilaka; 38. Valelevu; 39. Delainakoro; 40. Delainavadra / Delainaisoro. House: 41. Cakobau's House. Burial places: 42. Savena Cave; 43. Old Savuna (burials); 44. Wawa (old burials); 45. Kabalala (burials); 46. Korovou (burials); 47. Rokere; 48. Delainawaqaibonu (burials); 49. Uluibau cemetery. Water places: 50. Savuna water basin; 51. Savuna spring; 52. Korovou well; 53. Korolevu spring; 54. Naitarakucu well; 55. Daku bathing place.

(5.6\% and $94.4 \%$, respectively); and (3) pottery scatters are found in five places to the north and twenty-six to the south (16.1\% and $83.9 \%$, respectively).

\section{Sites and Surface Materials}

Although shell remains were relatively abundant, artifactual surface findings were almost totally limited to pottery. Fijian pottery has been the object of much inquiry 
Table i. Number of Archaeological Sites Recorded in the Survey, Grouped by ISLAND AND TYPOLOGY

\begin{tabular}{ll}
\hline ISLAND & \multicolumn{1}{c}{ SITE FORMS AND NUMBERS OF SITES BY CATEGORY } \\
\hline Moturiki & 31 surface pottery scatters without evidence of structures \\
& 1 Lapita site (Nunn et al. 2007, see below) \\
& 2 rock art sites (one of the boulders has only grinding marks, Cruz Berrocal and \\
& Millerstrom 2013) \\
& 10 ring-ditch villages \\
& 9 isolated yavus \\
& 18 terraces/house mounds (villages) \\
& 1 house (remains of a historical place, called Cakobau's house) \\
& 6 water sources \\
& 1 burial places (both ethnographic and archaeological) \\
Yanuca Levu & 1 terrace/house mound (high village) \\
Caqalai & 1 surface pottery scatter \\
Leleuvia &
\end{tabular}

(Best 1984; Birks 1973; Burley 2002; Frost 1979; Green 1963; Sand et al. 2007; Shaw 1967) within the framework of a four-period typology (Kirch 2000:157): (1) Sigatoka (c. 1200-100 B.C.), subsequently divided into Early Lapita, Late Lapita, and Plainware phases (Burley 2002); (2) Navatu (100 B.C.-A.D. 1100); (3) Vuda (A.D. 1100-1800); and (4) Ra (A.D. 1800 onwards). Slightly different chronologies have been assigned to the four periods by different scholars, and the main problem remains the matching of this typology (in any of its variations) to the entire archipelago (see Cochrane 2009:26-34; see Burley and Dickinson 2004 for an interpretation of Level 1 in Sigatoka as a local development). In spite of the chronological differences, some elements can be considered as diagnostic in all cases: dentate-stamped Lapita pottery in the Sigatoka phase; paddle-impressed pottery in the Navatu phase; incised, triangular-incised, shell-impressed, grooved pottery decoration in the Vuda period; and complexly incised, appliqué, raised patterns, and modeled pottery in the Ra phase.

We have relied on this simple typology to produce a working scheme useful to preliminarily classify the abundant pottery recorded both in 2008 and 2010, although it is important to note that only 28 sites could be ultimately classified (in some sites we just noticed plain pottery, and in some other sites we could not attest surface findings) (Fig. 5). We lack criteria to corroborate or propose alternatives to this four-fold typology, or to present a dynamic evolution of pottery, the potential existence of relict decoration and techniques, and differing chronologies or particularities in Moturiki in relation to the rest of the archipelago. But this is an inherent limitation of survey that we tried to lessen by carrying out test pits in different locations, with limited success (see below).

Variability of pottery decorations in Moturiki is large. Overall, the general Fijian typology presented above seems to fit with findings in Moturiki, although Ra pottery appears scarce and sometimes difficult to differentiate from Vuda pottery.

The association of this preliminary classification of pottery with archaeological sites produces some noticeable facts (Table 2; see also Figure 6). The Navatu phase is represented at three sites in the southern part of Moturiki: Korovatu, Daivetalevu, and Babadamu, a scatter on the northern hill of Korovatu. The Navatu pottery is therefore 


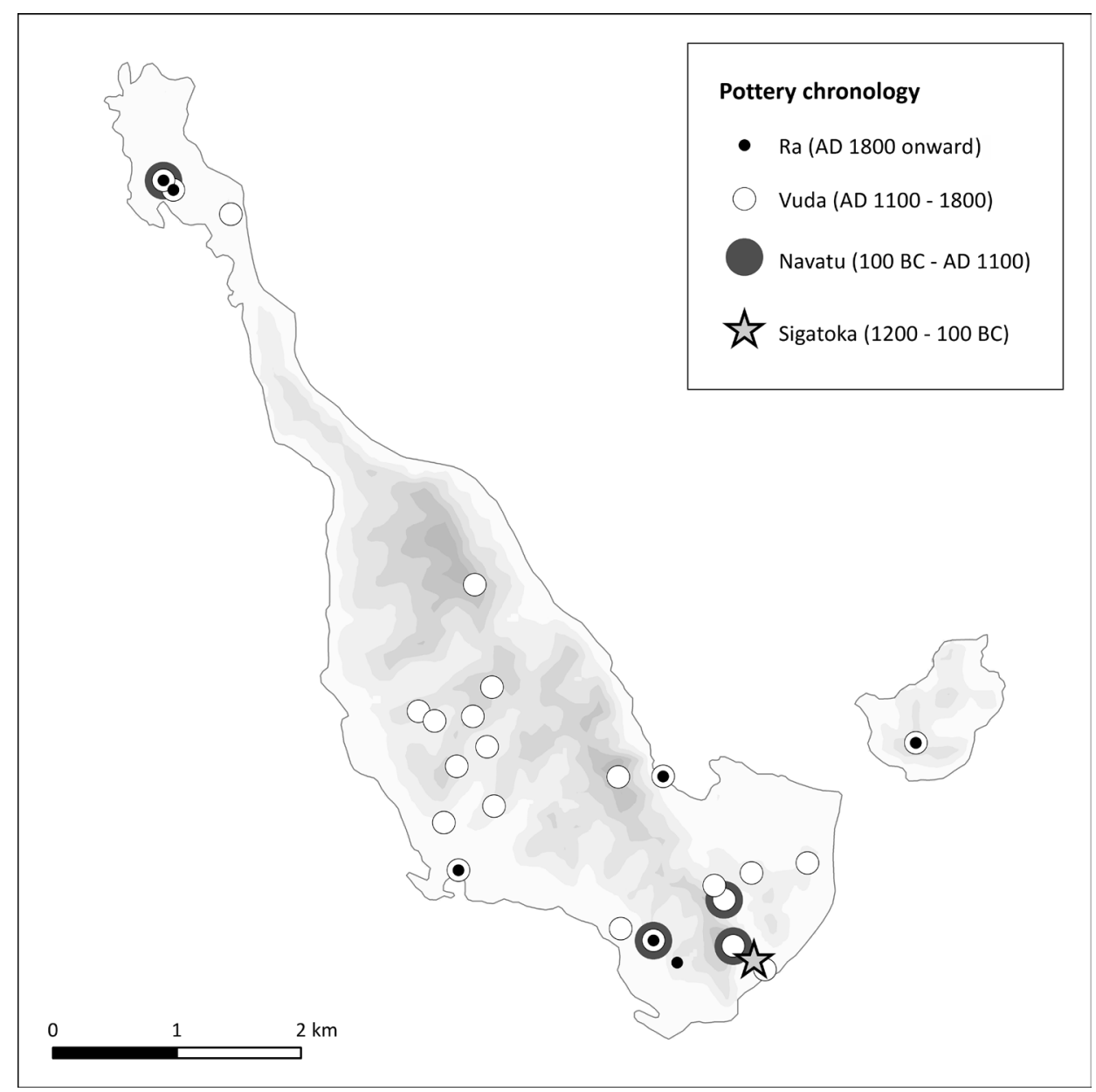

Fig. 5. Distribution of pottery by chronological period.

associated with village settlement; that is, settlement including terraces and house mounds. Only one site is found on the northern part of the island, an "outlier": a ring-ditch village (Old Savuna), a lowland settlement.

The Vuda phase in Moturiki seems to show an apparent explosion in population and settlement. We recorded Vuda pottery at 27 sites throughout the island, as well as Vuda remains in Yanuca Levu, Caqalai, and Leleuvia. These sites include both high villages and ring-ditch villages in both coastal and high areas, representing a diversification in the settlement patterns and an extension as well as an intensification of settlement. The appearance of abundant pottery in the islands off Moturiki (Yanuca Levu, Caqalai, and Leleuvia) also point to an expansion of population in this period. ${ }^{13}$

Finally, the Ra phase seems to represent an apparent constriction in population and settlement, with only nine sites recorded: Old Savuna (ring-ditch village) and Namotu in the north; Delainawaqaibonu (village and burial place), Daivetalevu, Korovou (ring-ditch village and burial place), and Nasara in the south. We also found 
Table 2. Archaeological Sites Found in the Survey: General Location, Chronological Ascription, and General Typology

\begin{tabular}{lll}
\hline SITE & CHRONOLOGY & SITE TYPE \\
\hline Korovatu & Navatu-Vuda & Terraces/House mounds \\
Babadamu & Navatu-Vuda & Surface pottery \\
Old Savuna & Navatu-Vuda-Ra & Ring-ditch village \\
Daivetalevu & Navatu-Vuda-Ra & Terraces/House mounds \\
Korolevu & Vuda & Ring-ditch village \\
Moturiki & Vuda & Ring-ditch village \\
Mataniwai & Vuda & Ring-ditch village \\
Mataitova & Vuda & Terraces/House mounds \\
Kororua/Navico & Vuda & Terraces/House mounds \\
Korogele & Vuda & Terraces/House mounds \\
Navitiro/Delanikoro & Vuda & Terraces/House mounds \\
Valelevu & Vuda & Terraces/House mounds \\
Delainakoro & Vuda & Terraces/House mounds \\
Nabureni & Vuda & Isolated yavu \\
Kabalala & Vuda & Surface pottery \\
& Vuda & Surface pottery \\
& Vuda & Surface pottery \\
Caqalai & Vuda & Surface pottery \\
Old Savuna & Vuda & Surface pottery (atoll) \\
Nasara & Vuda? & Terraces/House mounds \\
Korovou & Vuda? & Surface pottery \\
Delainavadra/Delainaisoro & Vuda-Ra & Ring-ditch village \\
Leleuvia & Vuda-Ra & Ring-ditch village \\
Namotu & Vuda-Ra & Terraces/House mounds \\
Delainawaqaibonu (burials) & Vuda-Ra & Surface pottery (Atoll) \\
\hline & Vuda-Ra? & Surface pottery \\
& Ra & Burial place \\
\hline
\end{tabular}

Ra pottery at Delanaivadra/Delainaisoro in Yanuca Levu and Leleuvia. That so few sites seem to be associated with Ra pottery may be partly due to the difficulty of distinguishing Ra from Vuda pottery. Even in some sites where pottery appears in association with glass and metal (e.g., Korolevu, discussed below), the pottery had to be assigned to the Vuda type. But in general, Ra pottery seems much scarcer than Vuda in Moturiki.

We observed a homogeneous distribution of pottery throughout the island, and we infer that variability in pottery decoration probably does not represent variability within the Fijian/Moturiki social formation at any time period. Likewise, the settlement types and land use through time seem to remain homogeneous throughout the island in each particular period, regardless of potential functional differences among sites. This is especially so in the southern highlands, where the settlement system seemed to combine enclosed sites (ring-ditch villages) and open sites with terraces (e.g., Kororua, Moturiki, Nawaqa). Furthermore, the pottery provides evidence of long-term occupation in 10 of the 27 classified sites: two Navatu-Vuda-Ra sites, two Navatu-Vuda sites, and six Vuda-Ra sites. This suggests that continuity from the Navatu through the Vuda and even to the beginning of the Ra period is possible.

As we pointed out above, there is, however, an observable difference between sites in the south and north. A preservation bias is possible in principle, given that the 


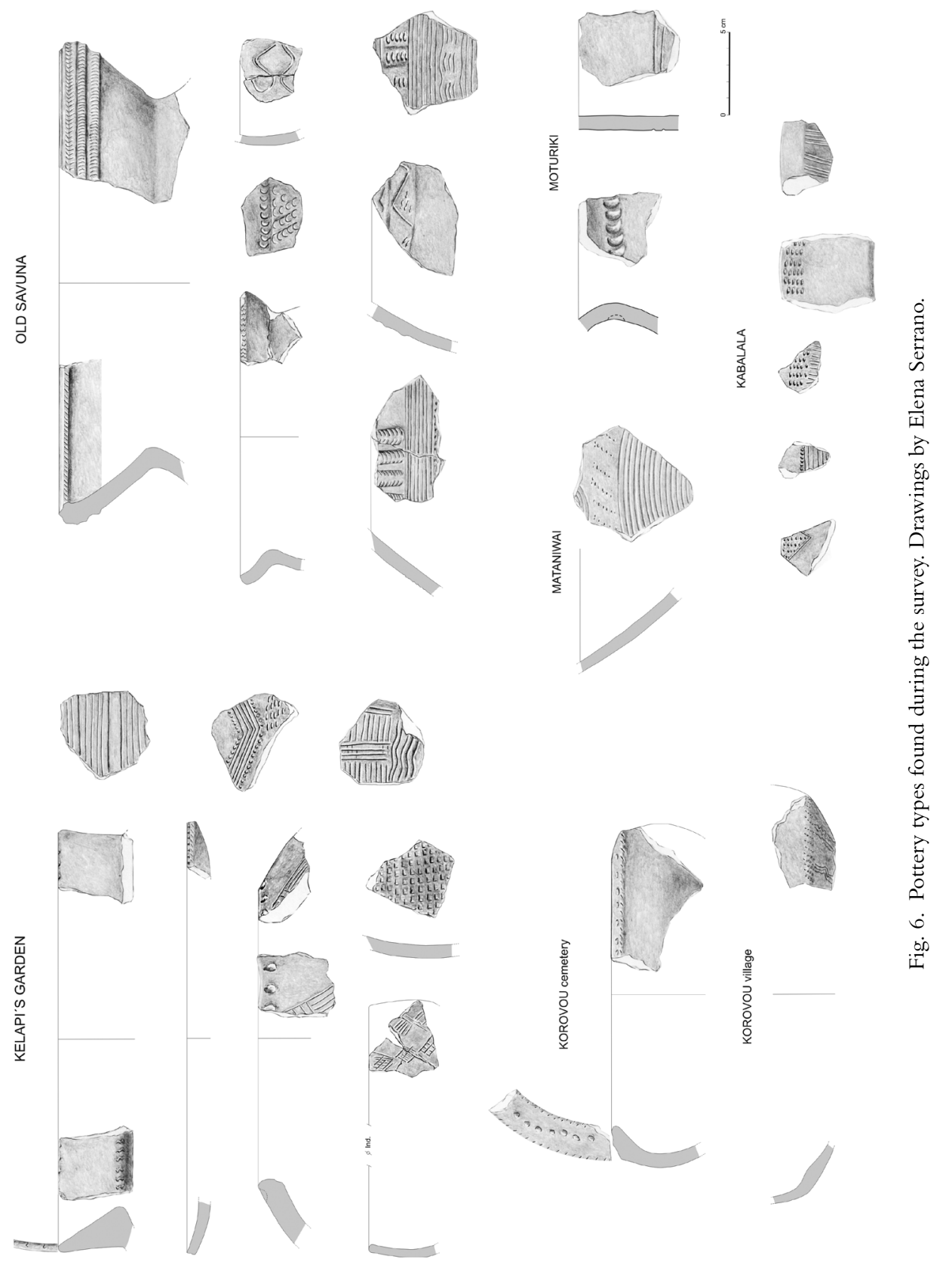


degraded vegetation in the north allows rains to wash materials down more easily than in the south. We nonetheless do not assume it generated the imbalance in the number of sites. Both archaeological sites and surface pottery are much less abundant in the dry, lowland north. Overall, the evidence suggests that the northern area had a weaker demographic element throughout history.

As yet, we have no relevant data for the origin of the pottery. Paste analyses have led archaeologists to suggest that Fijian pottery has been found as far away as the Marquesas (Allen et al. 2012; Dickinson et al. 1998). Nunn and colleagues (2007) propose that pottery in Moturiki could have had provenance in Kadavu (feldspathic temper), Lau (placer tempers), and Rewa Delta (quartzose tempers, like pottery fragments in the Marquesas). Since their analyses were based on 92 fragments of dentate-stamped pottery of Lapita provenance, it cannot be assumed that the same pattern of pottery making has been in place in Fiji since Lapita times. Future research should analyze the composition of ceramic pastes in Moturiki, as well as the post-depositional life of the pottery. However, with some exceptions (for instance the ring-ditch village in Old Savuna, which is surrounded by a swamp), our sample shows a poor state of preservation of surface pottery, which may hinder further analysis.

\section{Experiments in the Field: Test Pits}

In 2010 we excavated test pits in different locations in Moturiki in order to recover at least part of the settlement sequence and thus work out a relative chronology for our surface findings. This proved challenging. We opened three $1.5 \mathrm{~m}^{2}$ test pits on sites that showed abundant pottery and remains of apparent structures on the surface: two in Navukamai and one in Kabalala. Surface findings were contradicted by extremely weak archaeological layers.

Navukamai is part of the Korovatu site, a big terraced village. We opened two test pits in an area delimited by a terrace. Test pit 1 was placed on top of what appeared to be a yavu. It yielded plain pottery, very worn out and of small size within layer $1(0-25$ $\mathrm{cm}$ deep). No shells were found. Below $25 \mathrm{~cm}$, layer 2 was a yellow clay matrix, sterile in archaeological remains down to at least $50 \mathrm{~cm}$, where we stopped. This yavu, identified by its shape and a wall of stones (including what seemed to be steps) keeping the slope in place, was in fact a structure included within and situated at one corner of a larger terrace. The wall of stones was formed by two stone courses, below which we found natural clay. Under the stones we found small-sized, plain potsherds showing little wear and including the shoulder of a vessel. The pottery was not diagnostic.

Test pit 2 was placed nearby on the terrace, apparently an area of cultivation located within the terrace proper. In layer 1, a rich dark organic soil, shells and animal bone fragments appear, as well as plain potsherds (about 60 of small size) and some decorated fragments that can be ascribed to the Vuda phase (Fig. 7). Below $40 \mathrm{~cm}-$ layer 2, formed of more compact brown organic soil-some shell and potsherds still appear (plain and worn, one of them with finger marks). A fire level with abundant charcoal was associated with a level of stones at the bottom of this layer (including a fragment of pottery with fingerprints in the rim in association with charcoal). Below the stones the natural yellow clay appears at $70 \mathrm{~cm}$. This layer was archaeologically sterile.

The Kabalala site is located in a high area. Pottery was abundant on the surface and also within the first natural layer, consisting of very organic, dark, wet soil between 


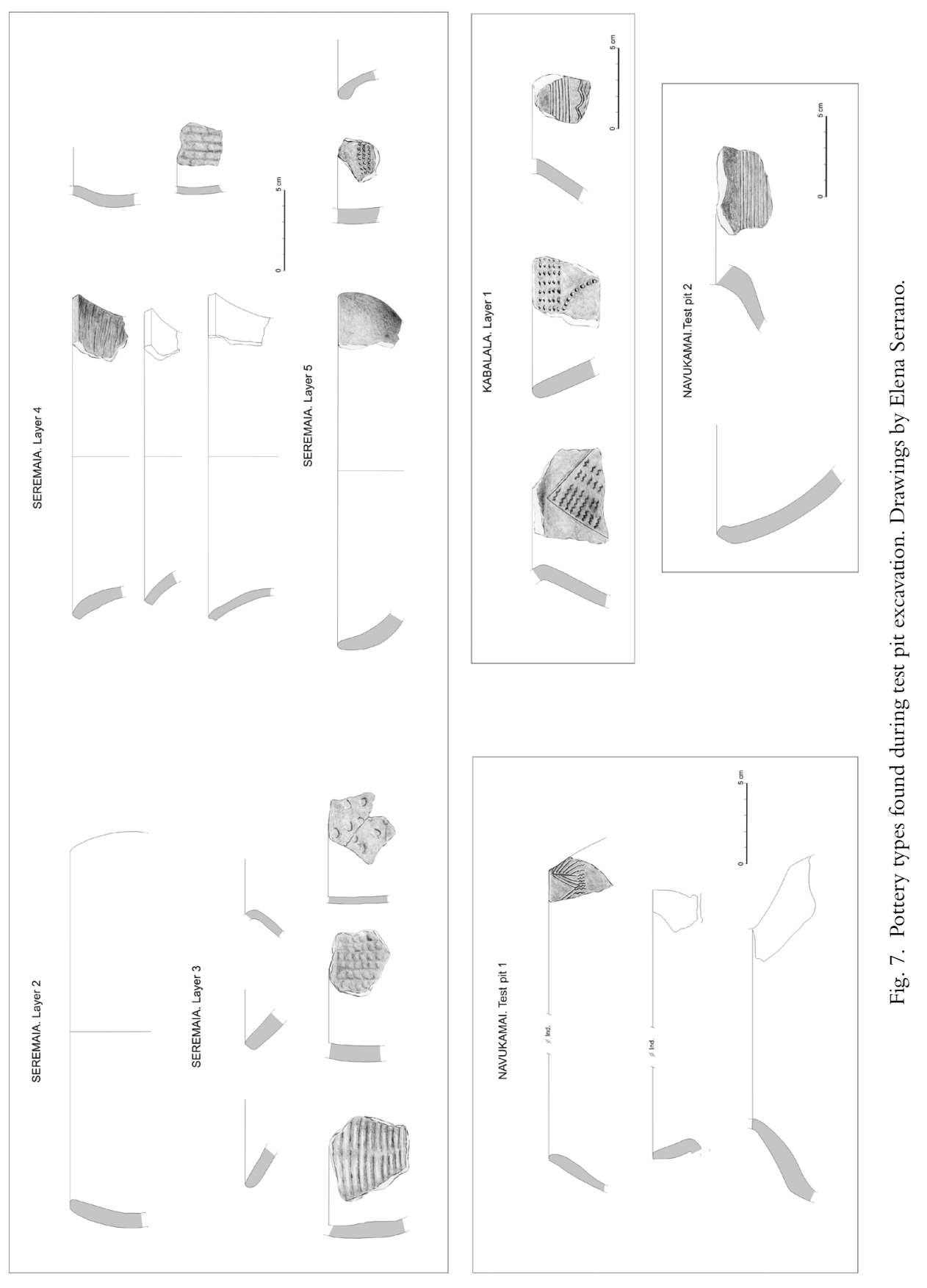


0-10 cm below the surface. In this layer, we found 73 fragments of pottery, plain, small, and worn, and some potsherds with decoration associated with the Vuda phase. Between 10 and $20 \mathrm{~cm}$, the sediment of layer 2 was light brown in color and less compact; we found 35 plain potsherds, mostly small and worn out. Between 20 and $35 \mathrm{~cm}$, the number of potsherds diminishes dramatically and the soil becomes yellowish in color. Below $35 \mathrm{~cm}$, sterile yellow clay appears. No shell was found in this test pit.

We suggest three explanations for these results: (1) preservation conditions have been extremely bad; (2) occupation levels were very short and weak, leaving scarce remains in the first place; or (3) the sites were dispersion areas of pottery in a secondary position. Laboratory analysis favors the third explanation, as we have been able to delineate possible areas of provenance for the archaeological materials on the surface (see above). This clearly shows the need for thorough analysis after fieldwork in order to define primary archaeological sites.

Whether these are primary or secondary sites, soil erosion likely contributed to their configuration due to two possible scenarios: Either debris was removed year after year by seasonal rains and clearing of vegetation, or both archaeological materials and soil were massively removed during particular events. Either situation would have deposited archaeological debris in lower areas.

In order to test the hypothesis that high areas in Moturiki might have been significantly altered by soil erosion in the past, we carried out a fourth $1 \mathrm{~m}^{2}$ test pit in a low area we called Seremaia, in Uluibau, close to the mangrove formation. The test pit was located at the foot of Korovatu, one of the highest hills on Moturiki. Since agriculture was not practiced there, no soil disturbance could be attributed to this activity. No structures, and only abundant, quite varied, evidently out-of-place pottery were found on the surface at Seremaia. We expected to find a sequence of pottery in secondary deposition coming from the slopes of Korovatu.

The excavation produced important amounts of pottery unequally distributed through seven layers (Fig. 8). The natural layers were found in a general horizontal disposition. Layers 1 through 4 were difficult to differentiate as they are all variations on a type of wet dark soil, very rich in organic remains, with a clay-sand matrix. Pumice is found scattered very sparsely throughout layers 2 through 5 , but layer 3 presents a heavy accumulation of pumice in a horizontal disposition.

Layer 5 represents a shift in the sequence. The sediment becomes yellowish sand, as this layer occupies the transition between the upper layers (1-4), formed by organic dark sediment, and the bottom layers (6-7). Layer 6 is formed by yellow beach sand, as is layer 7 , where sand becomes finer, with abundant coral. Pottery fragments in layer 7 do appear down to $170 \mathrm{~cm}$, at which depth we stopped for safety reasons. These potsherds are undiagnostic and probably percolated down from the upper layers. An unidentified animal bone fragment (jaw) of a fairly good size was found at $158 \mathrm{~cm}$.

Potsherds in layers 1-4 appear to present characteristics attributable to the Vuda phase, in spite of a lack of internal consistency and their being clearly in a secondary position. The potsherds are clearly worn, though a bit less so in layer 4 . Layer 5 presents scarce fragments of plain pottery and a single decorated paddleimpressed potsherd.

The ratio of plain pottery in relation to decorated pottery is much higher in every layer at Seremaia. However, there are no arguments to attest the sole presence of plain 


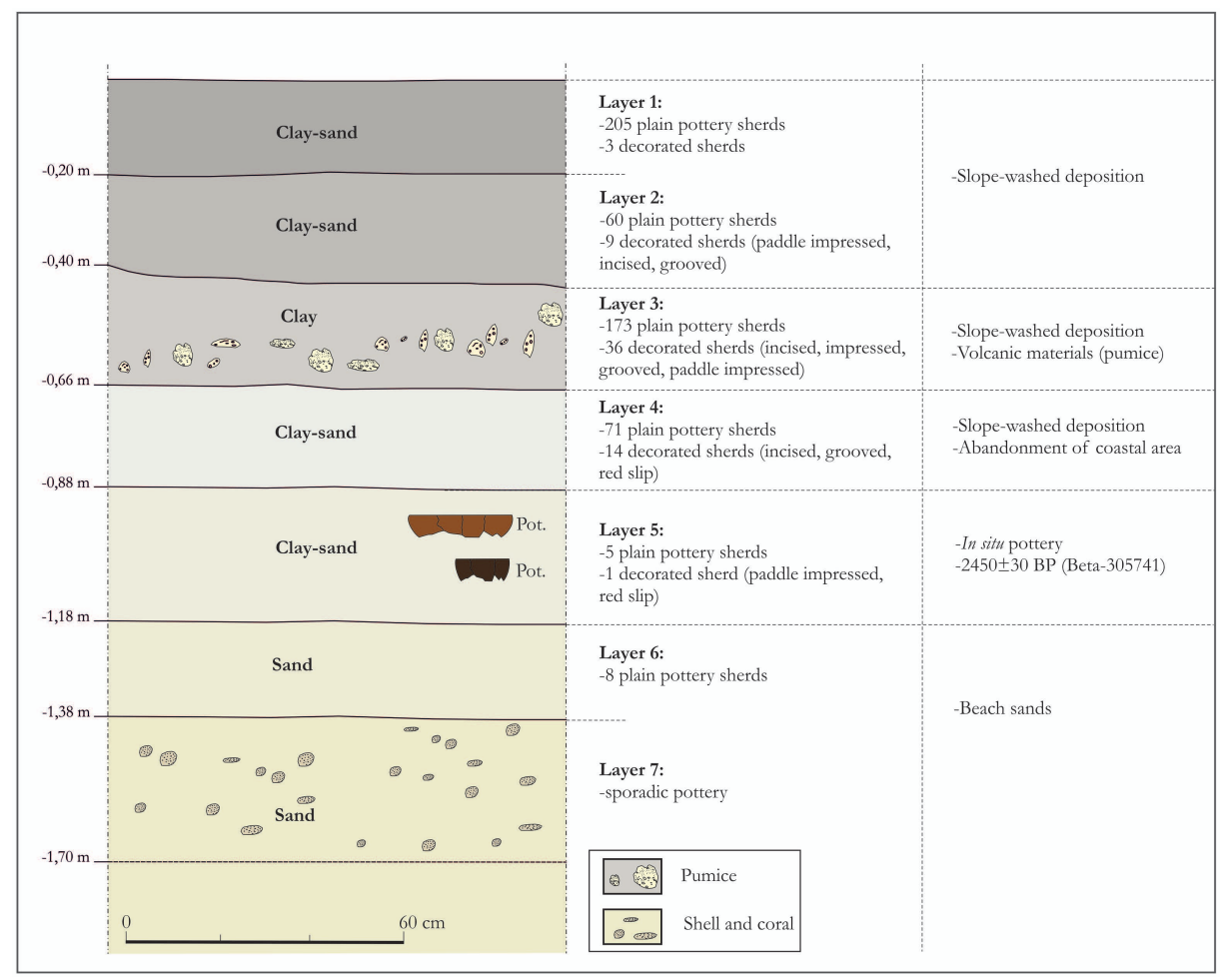

Fig. 8. Stratigraphic sequence in Seremaia. Drawing by Elena Serrano.

pottery in Moturiki at any time period, as it coexists with decorated pottery (but see Nunn et al. 2007). Indeed we recorded 12 sites where only plain pottery could be attested, but this fact does not contribute a sufficient argument to prove the existence of a period with only plain pottery, since its recovery during the survey was not exhaustive and vegetation is a very disturbing factor.

The Seremaia test pit rendered an unexpected finding. In layer 5, on the east side of the test pit, we found two accumulations of in situ pottery at $94 \mathrm{~cm}$ and $105 \mathrm{~cm}$. They were large fragments in a very poor state of preservation mostly due to extreme humidity; it was impossible to recover the fragments. The original vessel or vessels had been crushed in place. A potsherd associated with the in situ pottery has a red slip, a common feature of Lapita pottery (Bedford 2006).

A Beta Analytics determination on a charcoal sample associated with the in situ pottery has produced the date $2450+/-30$ B.P. (Beta-305741), or 730-690 B.C., 2 sigma calibration. This date is indistinguishable from dates by Birks (1973:57) and Burley and Dickinson (2004:17) for charcoal in association with Level 1 ceramics at Sigatoka (Late Lapita) that weighted an average of $2491+/-25$ вP.

\section{Soil Samples}

We collected soil samples from every layer in Seremaia. Juana Pérez-Arias and Santiago Ormeño performed the following analyses of the samples: (a) separation of rock 
fragments (RF) sieved at $2 \mathrm{~mm}$ diameter to obtain the percentage in weight in relation to the total sample using the equation: $\% \mathrm{RF}=$ (soil weight $>2 \mathrm{~mm} /$ soil weight $<2$ $\mathrm{mm}+$ soil weight $>2 \mathrm{~mm}) \times 100$; and $(\mathrm{b})$ pedological characterization of soil using soil samples $<2 \mathrm{~mm}$, involving (b.1) morphological and physical characterization of the soil, including (b.1.1) soil color and (b.1.2) particle size distribution analysis (Glendon 2002); (b.2) chemical characterization of the soil, including (b.2.1) pH and electrical conductivity (EC) and (b.2.2) organic matter content calculated as SOM $($ soil organic matter $) \%=(100 / 58) \times \%$ Organic Carbon $(\mathrm{OC})$, and (b.2.3) $\mathrm{CaCO}_{3}$ equivalent $\%$.

These analyses, together with previous observations about the distribution of pottery in the test pit, allow us to propose a summary of the processes detected in the Seremaia area (Table 3). Beach sands (layers 6 and 7) represent the original beach. On its northern fringe soil built up (layer 5) before people first settled the island. At some undetermined point in time after 730-690 B.C., the coastal area was abandoned and people began to settle on higher areas including the Korovatu site. Eventual clearing of the vegetation on the slopes and horticultural activities would have had a high hydric impact and promoted initial soil erosion, as observed in layer 4 and to a much larger scale in layers 1,2, and 3. The soil analysis confirmed the probable erosive origin of these layers based on their finer texture indicating a possible illuviation of clay and high concentration of soil organic matter (SOM), although this variable could also be caused by the mangrove environment at Seremaia. These layers could have further undergone edaphic processes after their deposition, producing incipient stratification and making it difficult to determine their upper and bottom boundaries.

Pottery seems to corroborate this assessment since potsherds in layers 1-4 are in clear secondary deposition. We have linked pottery within these layers to the Vuda period, while layer 5 has likely Lapita pottery in situ, as well as paddle-impressed potsherds.

The difference in preservation of potsherds between layers 1 and 3 and layer 4 may be explained by a slower rate of soil deposition, which can be confused with in situ edaphic processes. In fact, the boundaries between layers 4 and 5 are not clearly visible, and the finding of an in situ floor in layer 5 rules out the possibility of a further integral edaphic process in layer 4 (layer 5 also has pottery fragments apparently not related to the in situ pottery, but they correspond to the Navatu period) (Fig. 8).

The rate of soil deposition in Seremaia through time seems to have varied from the initial moments of occupation in the interior of Moturiki (Korovatu), associated with potential erosion of the slopes (layer 4), to later periods (layers 1-3) when deposition and therefore erosion seem to have accelerated. A further variable has likely influenced the rate and nature of deposition, namely the construction of agricultural terraces in Korovatu. It seems possible that deposition of sediment followed a different pattern once the terraces were in place, and that the bulk of the soil accumulated abruptly in Korovatu. But it is difficult at this stage in our research to determine if this happened, and if so, if it happened during the initial construction or later abandonment of the terrace complex and settlement. If the deposition happened during the abandonment phase, the potsherds in layers 1 through 3 would probably have been very worn prior to its final deposition in lowland Seremaia; since the pottery recovered in Seremaia in layers 1-4 seems to belong to the Vuda phase, this could indicate that 

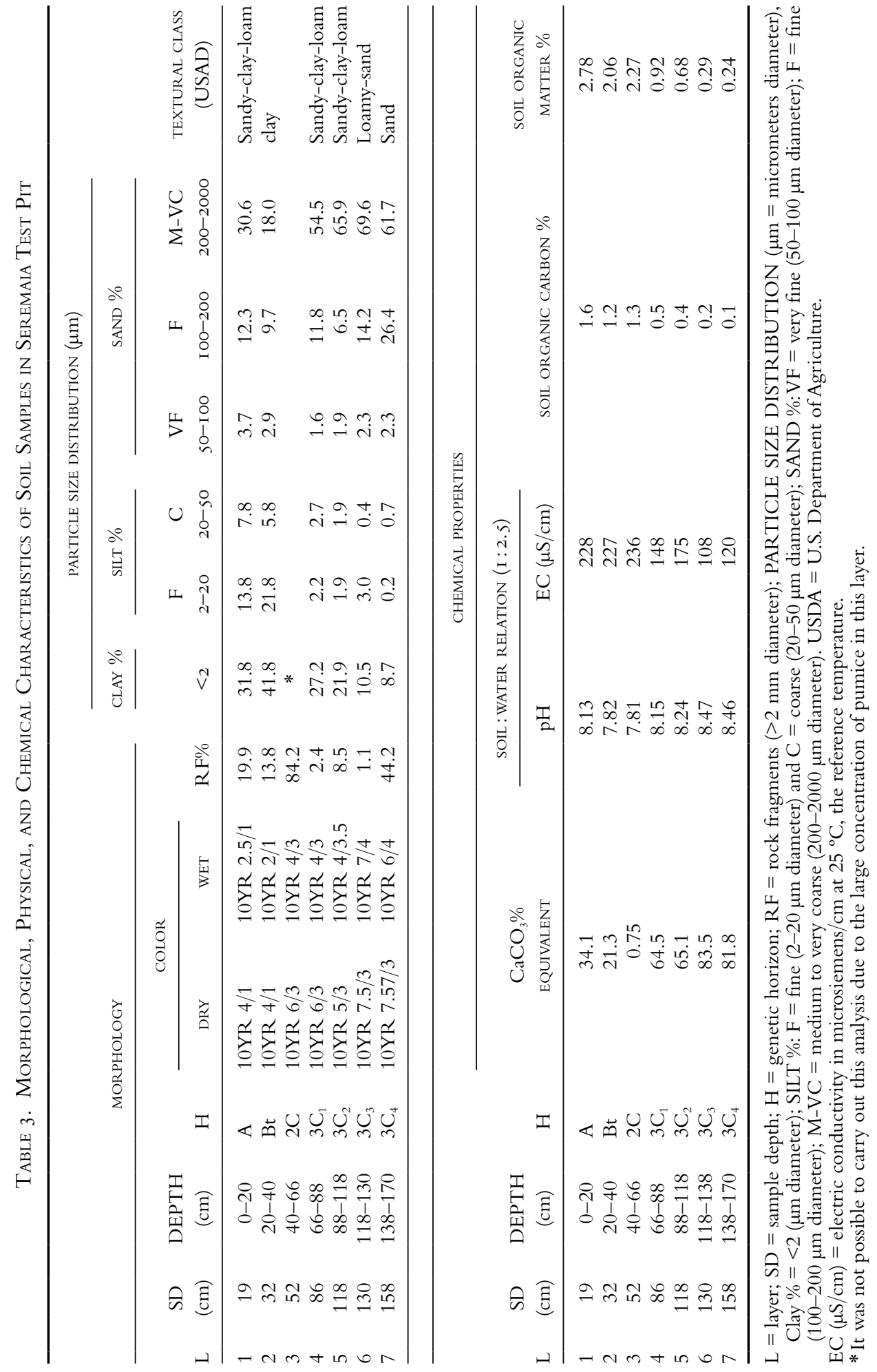
the terraces were abandoned in the last 200 years. Further research will be needed to test this hypothesis and address other questions such as the extension of terraces at any point in time and the possibility that some slopes were cultivated without terraces being built. It would also be important to corroborate that the terraces were both constructed and abandoned within the Vuda phase. In any case, the deposition of sediment from higher areas had an impact on the pedogenetic sequence in the Seremaia area.

The high concentration of pumice in layer 3 also warrants discussion, although at present we are unable to advance an explanation. Pumice is scattered throughout the layer, with a significant concentration between 45 and $65 \mathrm{~cm}$ below surface, especially on the east side of the test pit. The pumice concentration was so high that it took up most of the sample, preventing us from performing a particle size distribution analysis $(<2 \mathrm{~mm})$. We can neither support nor discard the hypothesis that a volcanic eruption produced this significant deposition of pumice along with other elements such as ashes. Pumice deposition can result from secondary processes other than the eruption itself, such as Burley and Dickinson (2004:20) have proposed for Sigatoka: "the occurrence of a layer of beach pumice between Levels 1 and 2 illustrates that the site was still within reach of storm waves at Level 1 time." In such a situation, the pumice could have drifted to the shore, having originated in a yet undetermined volcanic eruption. We attempted chronological analysis of a pumice sample at two laboratories (Natural Environmental Research Council [NERC] Argon Isotope Facility, hosted by the Scottish Universities Environmental Research Centre [SUERC], and Academia Sinica in Taipei), but determinations were impossible because the potassic material was too scarce in the samples. Since we were unable to determine a specific age for the pumice, a unique event resulting in its deposition could not be ascertained. Had we been able to do so, it would have established a useful chronological reference for the region. At this point it can only be stated that the population had abandoned the Seremaia area before the pumice was deposited.

A volcanic eruption could have advanced the shoreline of Moturiki. ${ }^{14}$ No doubt the question of land prograding is brought to the fore by our excavation in Seremaia, but in this case the presence of pottery in all layers suggests that human activity and deforestation account for the lion's share of the deposition. ${ }^{15}$

The date and the stratigraphic position of the in situ pottery in Seremaia matches the final moment of coastal occupation in Moturiki proposed by Nunn and colleagues (2007). They excavated thirteen $1 \mathrm{~m}^{2}$ test pits in nearby Naitabale in order to determine the existence and chronology of Lapita settlement in Moturiki. The size $\left(300 \mathrm{~m}^{2}\right)$ they proposed for the Naitabale site should probably be reconsidered and enlarged, as Seremaia could have been part of the original settlement.

Geomorphological characteristics of the two areas differ slightly. The beach sands in Seremaia begin at a depth of $118 \mathrm{~cm}$, while in Naitabale (following evidence from Pit T1) they could appear at $127 \mathrm{~cm}$. Nunn and colleagues (2007) found a burial of a woman (whom they named Mana) at $140 \mathrm{~cm}$ below surface. The shells associated with this burial along with six bone samples from the body were dated (Nunn et al. 2007) and they overlap only between 2740 and 2739 B.P. (790-789 B.C.). Nevertheless, Nunn and colleagues provide the oldest date for Lapita occupation in Fiji1260-970 B.C. (3210-2920 B.P.) — and suggest that "Lapita occupation of Naitabale is likely to have been about 2950-2600 cal years BP (1000-650 BC)" (Nunn et al. 2007 : 127). But they note that the Naitabale site has been subject to disturbance: 
In Pit R2, dentate-stamped pottery was encountered throughout the top $20 \mathrm{~cm}$ and is interpreted as having been redeposited from a location slightly upstream, perhaps during a flood. A second zone of dentate-stamped pottery is found around $60 \mathrm{~cm}$ and, because of the clay in the stratum, is interpreted not as a fluvial deposit but as colluvial, probably slope wash that carried Lapita material downslope from an adjacent location. The insitu Lapita layer in Pit R2 occurs between 105 and $125 \mathrm{~cm}$; the lack of stratigraphic consistency implied by the 3 charcoal dates is probably a function of old wood having been burned to create the middle sample. ${ }^{16}$ (Nunn et al. 2007:101)

It is also possible that current and probably past agricultural use of Naitabale could partially explain the stratigraphic characteristics of the site. Disturbance can actually be very pronounced at the site, which does not correspond with their assertion that "the Lapita settlement at Naitabale was not reoccupied by later people for any prolonged period of time, meaning that it is relatively undisturbed. For this reason, almost all the cultural material on the site is likely to be Lapita in age" (Nunn et al. 2007:101). Although we do not necessarily agree with this assertion, the Seremaia test pit seems to attest to the reliability of materials found in situ in Naitabale at around $1 \mathrm{~m}$ below the surface. ${ }^{17}$

Nunn and colleagues (2007:101) further propose: "Later occupants of the site generally seem to have lived as close to the shoreline as the Lapita people, meaning that they occupied the lee of the beach ridge closest to the shoreline." It is not clear what is meant by "later occupants," and since this appears somewhat contradictory to their assertion that later people occupied the site even if not for prolonged periods, it is difficult to understand the history of the place. However, the complex stratigraphy in Naitabale and the abundant pottery recorded there could match our interpretation of a marked change in the settlement patterns in Moturiki. ${ }^{18}$ People could have moved inland after the Lapita period, rather than toward the coast, especially as the surface pottery we found in Naitabale seems to belong to the Navatu phase.

Nunn and colleagues (2007:101) further suggest that "increasing amount of terrigenous sediments being carried to the shoreline by rivers like the Mataloaloa has led to shoreline straightening and progradation of $250-350 \mathrm{~m}(8-10 \mathrm{~cm} / \mathrm{yr})$ along this coast." The sea level would have been at least $1.45 \mathrm{~m}$ higher at 950 в.c. before subsequently falling, allowing people to move toward the coast (Nunn et al. 2007:101).

Seremaia is $150 \mathrm{~m}$ to the southwest of Naitabale (Mana burial) and about $160 \mathrm{~m}$ inland from the current coastline. The fact that the in situ pottery in Seremaia was indeed on soil, probably derived by an edaphic process on the sand at beach level, provides evidence for a higher sea level while the process of soil deposition in the Seremaia area was starting to take place. We cannot assess the lapse of time between the deposition of the pottery in situ in layer 5 and the formation of layer 4 . That there are no sterile layers above layer 5 could mean that soil deposition in the area is inherently associated with human activities in Korovatu, probably inhabited early in the history of Moturiki. Thus, we would ascribe a much more important role to human activity in the environmental history of Moturiki than Nunn and colleagues (2007) acknowledge. In our view, even allowing for periods of heavy rain and flooding, the rivers in Moturiki (including the Mataloaloa) are not powerful enough to account entirely for the deposition of soil on the coastline. Further environmental analyses should be carried out in order to determine the origin of the sedimentation process that took place contemporarily to the falling sea level. 


\section{DISCUSSION}

The preliminary results presented here allowed us to generate tentative conclusions and raised further questions regarding the prehistory of Moturiki, particularly around occupation sequences and changes in settlement patterns and the landscape.

\section{Occupation Sequences}

The finding of in situ pottery in Seremaia seems to corroborate Nunn and colleagues' (2007) dates for the final occupation of the coast. Further inquiries should shed light on subsistence practices during this occupation. The reef in this part of the island is large, which would have permitted procurement of important marine resources. Evidence for this would corroborate the idea that early Lapita settlers occupied the most attractive seashores (e.g., Kirch 1997). Although Nunn and colleagues (2007) reject the possibility of agriculture in the area, ${ }^{19}$ we consider it likely given that Naitabale is located on the best agricultural land in Moturiki. We have not yet been able to conduct palaeobotanical analyses to ascertain whether domestic crops were introduced at this time.

\section{Changes in Settlement Patterns}

We recorded a significant change in settlement patterns through time, from the oldest attested sites in the island (Naitabale and Seremaia) to current villages. Original colonization on the shoreline was subsequently followed by the occupation of the interior, as attested by abundant material remains. At some undetermined point in the recent past, people left the interior and went back to live on the coast, where all nine modern villages are located. Oral history relates this return to the coast to the introduction of Christianity in 1855, but more archaeological research should be done in order to assess the chronology of this pattern.

Very few historical archaeological remains have been examined so far in Moturiki (an example is the well-preserved china found at the site called Cakobau's house). We attested to a glass bottle and a metal fragment consistent with a pot used for blubber processing (one of these pots is still to be found in Leleuvia), together with Vuda pottery in Korolevu. Thus, the contact period with Europeans seems to be represented in Moturiki, and our findings show a probable late abandonment of pottery making on the island, as well as a movement from the protected, ring-ditch villages in the interior to unprotected villages on the coast. The change in settlement patterns from the coast to the interior and back to the coast does not seem related to economic and subsistence practices and, therefore, environmental change, partially because the size of the island does not seem to count as a factor. The change in settlement occurs both in Moturiki and Yanuca (only about $1 \mathrm{~km}^{2}$ ), where people are currently living on the lowlands after abandoning a large terraced village on the hills of this tiny island. Social and political factors should explain the pattern, which is also documented in islands such as Lakeba (Fiji) (Best 1984) and Tiga (New Caledonia) (Lilley et al. 2012). ${ }^{20}$

The archaeological landscape of interior Moturiki testifies to dense occupation in the past. Not only the density of remains but also size suggest an increase of population numbers in the south of the island, more so in the Navatu and above all Vuda periods. Settlement was dense and concentrated in high villages. It was also extensive, 
taking advantage of isolated hilltops where normally one or two houses are to be found; these were probably associated with agricultural activity. The intensive occupation of the territory is also seen in the altitudes of the sites: Villages and isolated yavus are distributed through the entire range of altitudes in Moturiki. Although they predominate at intermediate heights, they are also found from the coastal level up to $116 \mathrm{~m} .^{21}$

It is likely that people from Moturiki were also using Caqalai and Leleuvia for agricultural purposes. Both atolls present abundant plain and Vuda pottery remains and no other visible structures. Their use during the Vuda period (probably taking advantage of underground water sources) would be in line with high occupation rates and intensive agricultural production in Moturiki.

Intensive exploitation of the Moturiki interior resulted in intensive work investment on: (a) building ditches and other defensive structures; (b) building terraces; and (c) conditioning works for irrigation of the agricultural plots. Most of this conditioning work is to be observed today in the landscape but it is archaeologically invisible (for instance, the raised fields), although some structures such as water deposits and wells have been recorded. Lack of water during drought periods seems to have been a relevant problem in Moturiki, as no important rivers run through the island.

Ditches are a very important feature of the archaeological landscape in Moturiki. They are part of ring-ditch villages. The ten sites included in this category are all located in Moturiki, both on coastal areas (four sites: Old Savuna, Korolevu, Nasara, Korovou) and highlands (six sites: Nawaqa, Soso, Koronisici, Moturiki, Mataniwai, Sawaikede) (Figs. 9 and 10).

It is often difficult to record the ditches around the villages because they have been destroyed by growing swamps, devoured by vegetation, or reused as agricultural land (especially for taro). This is a fairly frequent occurrence, and it is possible that in the past the ditches were used as alternative cultivation areas, especially in highland sites where their defensive function could have been more supportive than essential. For example, Koronisici and Moturiki would have been difficult to attack anyway because they are located on tops of summits.

Whenever possible, we calculated the approximate size of the ring-ditch villages using GPS information captured during the 2008 and 2010 field seasons, in order to obtain an impression of the work investment demanded for their construction (see Table 4 for interior diameter and ditch width). These figures are consistent with those presented by Parry (1997:107, figure 5.4) for the northern coast of Viti Levu. The homogeneity of the dimensions of the villages and their locations in coastal and highland areas suggest that there was a certain amount of what we could call political mimesis among these different units.

Other defensive structures were recorded in Navitiro/Delanikoro, a terraced village. Navitiro Fort is an earthwork construction with an east-west orientation and the following dimensions: wall width $1.40 \mathrm{~m}$; height $50-60 \mathrm{~cm}$; maximum interior length of the structure c. $28 \mathrm{~m}$; interior width $7 \mathrm{~m}$. The walls consist of 3-4 stone courses on both sides, especially to the north; the walls were then filled with soil. No pottery and only a few shell fragments were found. There is a concentration of stones/boulders near the north wall, possibly a pavement or sleeping area. Moreover, on the summit of Delanikoro hill we documented a smaller structure with 


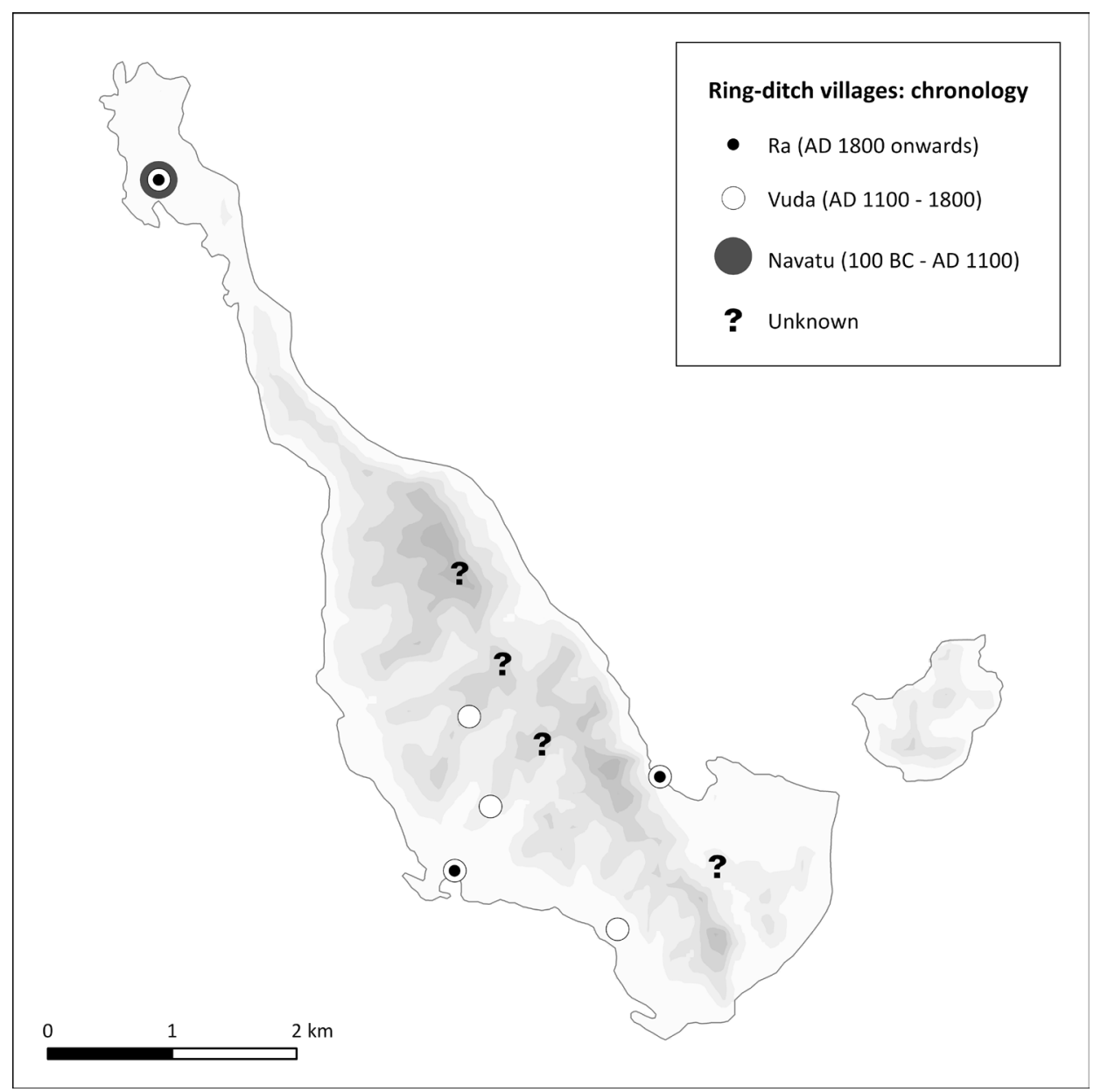

Fig. 9. Distribution of ring-ditch villages in Moturiki, with chronological indication when possible.

an exterior length of $5 \mathrm{~m}$, exterior width of $4.80 \mathrm{~m}$, and a maximum wall height of $0.7 \mathrm{~m}$. This is the highest point in the area, where presumably people could have gone for safety reasons.

We also documented Nasiriva Fort, a stone-lined platform $7 \mathrm{~m}$ long, $1.5 \mathrm{~m}$ wide, and about $0.5 \mathrm{~m}$ high. This complex is part of a fort running roughly north-south with walls some $1.50 \mathrm{~m}$ wide and $1.30 \mathrm{~m}$ high. The opening is $1.70 \mathrm{~m}$ wide. Coral blocks make up part of the stone facings of the structures. A substantial amount of shells, especially troca and bivalves, were found, along with some plainware.

The sizes of these structures, which we have interpreted as serving a defensive function, show that they could in fact be scattered throughout Moturiki, having an important relevance in daily life, much more than we have been able to record archaeologically in our fieldwork.

A good deal of work was also devoted to the construction of agricultural terraces, both within sites without associated settlement and within villages. Delainavadra site 


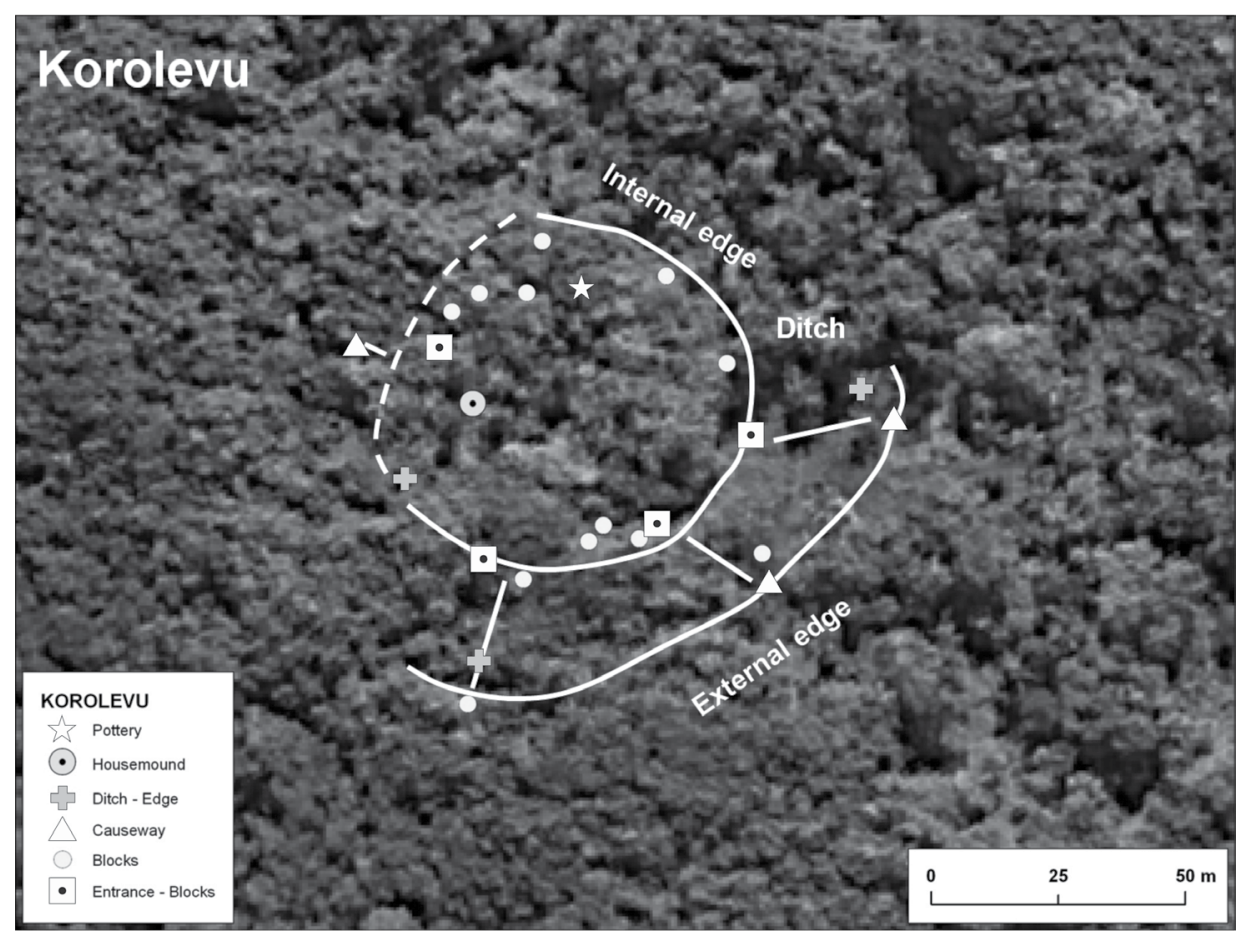

Fig. 10. Reconstruction of the Korolevu ring-ditch village.

in Yanuca Levu exemplifies this. This village has numerous terraces on its north side. We recorded at least nine levels formed by superpositions of up to five stone courses of mostly large $(50 \times 50 \mathrm{~cm})$ boulders still preserved in place (Fig. 11). The facing walls of the terraces rise up to $1 \mathrm{~m}$; the dimensions of the terraces vary from 7 to $25 \mathrm{~m}$ long and from 5 to $8 \mathrm{~m}$ wide. These measurements are not precise due to the difficulties in the recording process, so our calculations may be underestimations. The figures nevertheless convey an idea of the dimensions of these structures.

Agricultural activity and settlement seem to have been complementary even at higher altitudes. Terraced agriculture probably allowed for intensification of production. The landscape likely included houses and gardens on terraces, as well as domestic groves. Most terraces were abandoned at a yet-to-be determined time; and secondary forest thrived over the abandoned terrace sites.

Today, agriculture is practiced in highly productive swamps and on the slopes using predominantly slash-and-burn techniques; the existing terracing infrastructure is disregarded. Slash-and-burn agriculture requires three-year rotations since the soil is exhausted after this period. Slopes must be continuously cleared to make way for new plots. In certain parts of the island, overexploitation of the land over the course of just one generation has resulted in total deforestation and unproductive soil. More analyses should be carried out in order to determine the degree of soil fertility on the terraces, the work investment needed to keep them in good shape, and their potential for agricultural production. If this were demonstrated, terraces could eventually be used again, with soil preservation goals in mind. 
Table 4. Approximate Sizes of Ring-Ditch Villages Measured using GPS Information

\begin{tabular}{|c|c|}
\hline SITES & SITE MEASUREMENTS AND NOTES \\
\hline \multicolumn{2}{|c|}{ COASTAL SITES } \\
\hline Old Savuna & $\begin{array}{l}\text { Approx. } 32 \mathrm{~m} \text { between entrance and house at center of site. Only one side } \\
\text { of village could be recorded due to destruction caused by growing swamp. }\end{array}$ \\
\hline Nasara & $\begin{array}{l}\text { Approx. internal diameter, } 55 \mathrm{~m} \text {. GPS measurements irregular, but recorded } \\
\text { area of village is } 2361 \mathrm{~m}^{2} \text {. Extreme values in the axes NS and EW are, } \\
\text { respectively, } 70 \text { and } 60 \mathrm{~m} \text {. }\end{array}$ \\
\hline Korolevu & $\begin{array}{l}\text { Approx. internal diameter, } 60 \mathrm{~m} \text {. GPS measurements irregular, but SE area } \\
\text { is well determined. Width of ditch, } 20-25 \mathrm{~m} \text {. (see Fig. 10) }\end{array}$ \\
\hline Korovou & $\begin{array}{l}\text { Approx. internal diameter, } 60-70 \mathrm{~m} \text {. Measurements taken mainly on NE } \\
\text { side due to destruction caused by growing swamp. }\end{array}$ \\
\hline \multicolumn{2}{|c|}{ HIGHLAND SITES } \\
\hline Soso & $\begin{array}{l}\text { Approx. internal diameter, } 86 \mathrm{~m} \text {. Some GPS measurements taken } \\
\text { alternatively on the exterior and interior sides of ditch due to difficulties } \\
\text { moving around site. }\end{array}$ \\
\hline Nawaqa & $\begin{array}{l}\text { Two main axes: NS axis about } 80 \mathrm{~m} \text {; EW axis reaches about } 40 \mathrm{~m} \text {. Area, } \\
2291 \mathrm{~m}^{2} \text {. Nawaqa means the shape of a boat, per our guide. }\end{array}$ \\
\hline Koronisici & Approx. internal diameter, $80 \mathrm{~m}$. Area, $5084 \mathrm{~m}^{2}$. \\
\hline Sawaikede & $\begin{array}{l}\text { Approx. internal diameter, } 45 \mathrm{~m} \text {. GPS measurements were taken on } \\
\text { opposite sides of the enclosure. Area, } 1590 \mathrm{~m}^{2} \text {. }\end{array}$ \\
\hline Mataniwai & $\begin{array}{l}\text { Approx. internal diameter, } 55 \mathrm{~m} \text {. Width of the ditch, approx. 9-13 m. NS } \\
\text { axis, } 55 \mathrm{~m} \text {; EW axis, } 35 \mathrm{~m} .\end{array}$ \\
\hline Moturiki & NW-SE axis, approx. $120 \mathrm{~m}$; NE-SW axis, approx. $70 \mathrm{~m}$. \\
\hline
\end{tabular}

Coastal ring-ditch village sites are located at a mean height AMSL of around $11.25 \mathrm{~m}$, while highland sites are located in a range of altitudes between 34 and $112 \mathrm{~m}$, with a mean height around $68 \mathrm{~m}$.

\section{Landscape Changes}

Landscape changes may have been significant in Moturiki since humans arrived on the island. Our observations relevant to landscape changes in Seremaia can be summarized as:

1. The existence of a sandy substrate (layers 6 and 7) over which soil built up by an in situ edafization process (layer 5). ${ }^{22}$

2. Human settlement on layer 5, current at least up to 730-690 в.C.

3. Abandonment of coastal occupation and settlement on the interior and high areas, eventually producing deforestation, hydric erosion, and soil washing down.

4. Pumice deposition due to unclear causes produces a lithological discontinuity in the profile. Human abandonment of the area had already taken place.

5. Continuous occupation of high areas and episodes of heavy soil deposition in low areas (Seremaia layers 1-4) with ongoing processes of edafization interrupted by new episodes of soil deposition.

Some of the features in this sequence lead us to propose that human activities resulting in deforestation and soil erosion had a strong impact on the landscape, especially in the low areas in the southern part of the island. Nunn and colleagues (2007) propose that soil deposition could have expanded the coast by as much as $350 \mathrm{~m}$, although they do 

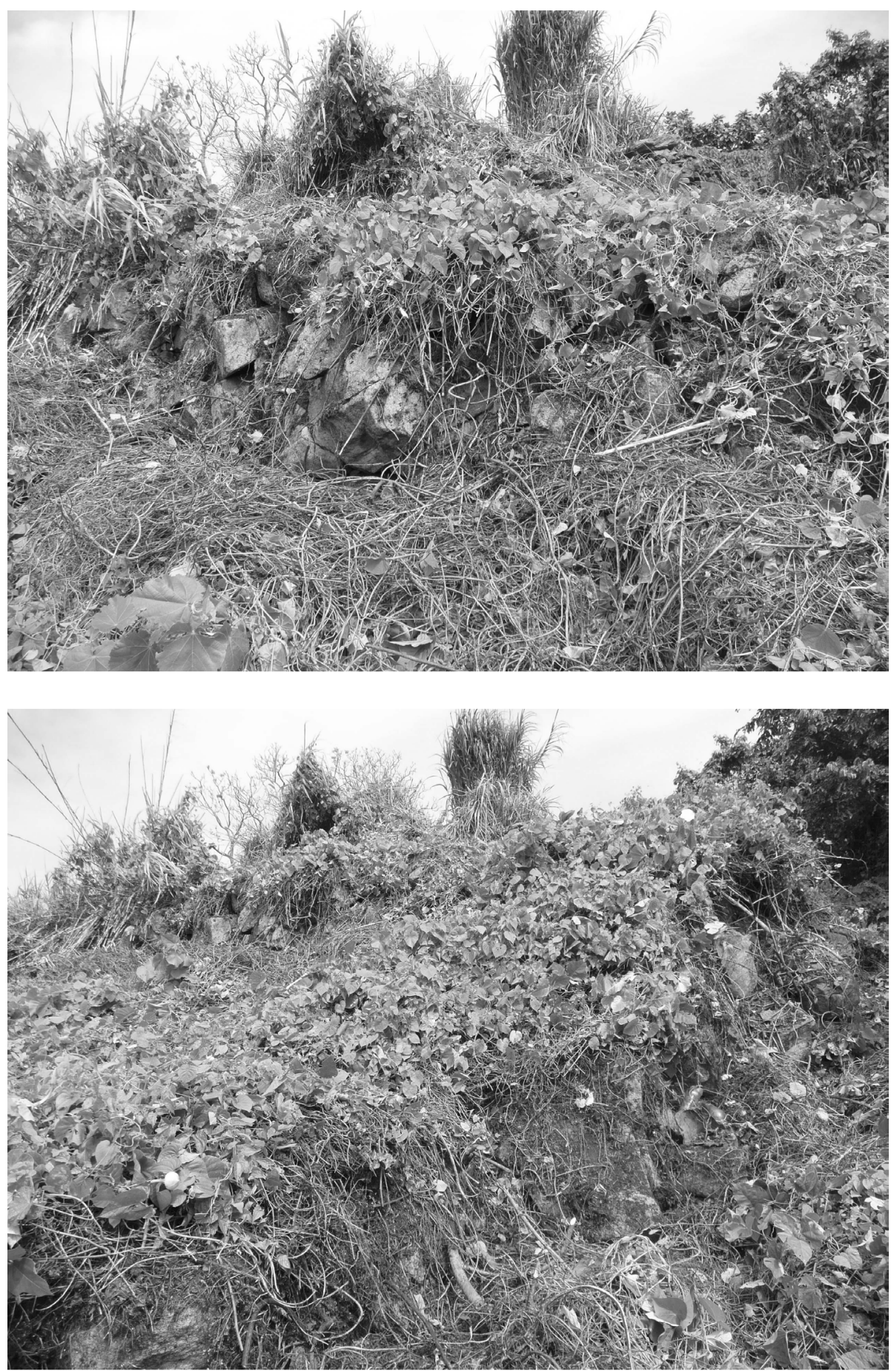

Fig. 11. Two views of the remains of terraces in Delainavadra, Yanuca Levu. 
not point to human causes. The current distance from the Seremaia test pit to the beach is $160 \mathrm{~m}$, but we cannot assess how much the coast expanded because the findings in Seremaia were located on built-up soil, not on sand beach.

During our survey of the interior of the island, we looked for evidence corroborating episodes of heavy soil deposition. We did not find constructed structures surrounding swamps that could have contained it. Thus, although it is not possible to corroborate intentionality in the creation or maintenance of swamps in the interior of Moturiki (they are highly productive in agricultural terms), we believe that at least some of them could have been the result of human alteration of landscape, and humans did profit from them. Likely examples include the swamp located on the path from Uluibau to Niubasaga, and Vatu Vola, in Naisogorourou, where a boulder with rock art was found buried (Cruz Berrocal and Millerstrom 2013). Although the swamp might already have existed when the rock art was made, its topography makes it likely that the boulder was washed there by soil and buried, and therefore that the swamp was formed after the making of the rock art. It was used for agricultural purposes until recently.

It is not likely in our view that the modification of the landscape led to environmental constraints that prompted the intensification of agricultural production. Rather, it seems that growing population numbers in conjuncture with increasing social complexity and maybe conflict (as seen in other areas in Fiji) prompted this development. Although there are few mentions of Moturiki in historical accounts, Sahlins has dealt with relationships between Moturiki and Bau:

To complete the geophysical dimensions of this historic recovery of the Bauan arche, we need only mention that the subject islands-especially Koro, Moturiki, Ovalau, and Nairai-contributed significant resources for mobilizing the Bau armies, sustaining them on campaign and rewarding their successes. Such levies on Bauan subjects, however, were not always designed to encourage their loyalty. (2004:116)

During the war between Rewa and Bau in 1843-1845, in January 1844, "Bau also recruited an army from Moturiki and Ovalau - a formally organized force known as the Pet Pigs ( $\mathrm{Na}$ Geti) — and deployed it to some advantage against Tokatoka, an important border ally (bati) of Rewa" (Sahlins 2004 : 277). Moreover, Sahlins (page 96) tells of how men were chased on Moturiki to be devoured on Bau, since Moturiki was Bauan land.

\section{CONCLUSIONS}

Some of the points we've made should be substantiated with future research. However, we can state that in spite of its position within a "transitional" island group between Tonga and Fiji, the history of Moturiki seems to match other areas of Fiji in terms of pottery remains, construction of defensive structures on hilltops, and settlement patterns. Indeed Moturiki seems to have followed similar paths as islands such as Lakeba (Best 1984). Especially in regard to the Vuda period (most represented in Moturiki), our case study fits the pattern described by Kirch (2000:157-158) for Fiji: extensive modification of landscapes for food production, widely differing residential patterns, and fortified villages. This situation parallels that in New Caledonia, especially in the construction of agricultural terraces (e.g., Sand 1996a, 1996b).

In our view, the size difference among islands such as Moturiki, Lakeba, or Yanuca Levu makes it difficult to ground an explanation of the shift in settlement patterns 
solely on environmental circumstances or demographic growth, since these processes would hardly have had an equal effect on such a variety of islands. Furthermore, a settlement shift toward the interior of the islands does not automatically guarantee a better food supply. We believe that sociopolitical conditions would have been critical in pushing people to the interior. Archaeology shows that even in the circumscribed environments of relatively small islands, there is enough leeway to allow for different ways of using the land. The archaeological landscape testifies to a scenario of mutable ways of life in these islands.

\section{ACKNOWLEDGMENTS}

We wish to acknowledge support and encouragement from Ian Lilley, Pedro Díaz del Río, Maribel Martínez Navarrete, Scarlett Chiu, Sagale Buadromo, Jone Balenaivalu, Juan Vicent, Concha Martín, and Julián Martínez. Thanks also to Juan Gaspar Leal Valladares, who worked in the field with us for several weeks. Invaluable help was given to us by Nicholas Tripcevich (ARF, University of California, Berkeley) to prepare the fieldwork and to process data. We also wish to thank Edwin Liava'a from the Applied Geoscience and Technology Division of the Secretariat of the Pacific Community (SOPAC). Meg Conkey was key in the implementation of the project.

Fieldwork would have been impossible without support from Dr. Sagale Buadromo, director of the Fiji Museum in Suva, and Jone Balenaivalu, also from the Fiji Museum. In the field, Sepeti Matararaba, Sitiveni Namua, Peni Vitu, Kelepi Tikoibuca, Inoke Draunidigala, Manasa Vuanisinugaga, Enoke Vuanisinugaga, Kesa and Timoci Bukasoqo, and the many people who lodged us, worked with us, and supported us in various ways during our stay in Fiji, deserve our warmest thanks. We are especially grateful to the assistance and the warm welcome of the people in Moturiki.

Funding for this research was provided by the Pacific Rim Program, University of California, 2008 (grant 08 T PRRP 01 0012, directed by Margaret Conkey), and the Ministry of Culture, Spain (grant SGIPCE/AMC/cmm, Arqueología exterior 2010, directed by María Cruz Berrocal). This article was written while María Cruz Berrocal was a researcher at the Institute of History, Centro de Ciencias Humanas y Sociales (CCHS), Consejo Superior de Investigaciones Científicas (CSIC) in Madrid and while she enjoyed a Ministry of Foreign Affairs (MOFA) Taiwan Fellowship as a Visiting Scholar at National Taiwan Normal University \& Institute of History and Philology, Academia Sinica, in Taipei, Taiwan, in 2013. The final stage of the publication was also kindly supported by the EU FP7 Marie Curie Zukunftskolleg Incoming Fellowship Programme, University of Konstanz (grant 291784).

\section{NOTES}

1. Analogical maps were obtained at the Government Building, Geographic Department, Suva.

2. ASTER GDEM, available from NASA's Jet Propulsion Laboratory, California Institute of Technology website at http://asterweb.jpl.nasa.gov/gdem.asp.

3. QuickBird images available at http://www.digitalglobe.com.

4. Land Use Section, Agriculture Department, Koronivia, January 1980.

5. Fiji LIS Native Land Maps \& Databases.

6. It could probably be argued that we tended to extract "too much" information from informants, for instance asking them to translate place-names. These translations tend to vary, since they are necessarily interpretations: If asked, informants would contrive to find a significant meaning out of what for them were just place-names up to that point.

7. It is interesting that a tale about African origins of Fijians was often told to us in the field as if it were oral history, but it was apparently created during the nineteenth century.

8. For example, Paula Rock, a boulder on top of a ridge and the highest point on Vouvou Mountain, is associated with a legend heard from Sitiveni Namua and recorded by Sidsel Millerstrom on 17 September 2008 (who added the information contained in the brackets), that established that 
Paula Rock is a tall upright that is part of the mountain. It symbolizes the second "man" or clan that inhabited Moturiki. An old man (Paula and his clan) came from Bureta (Bureta river area, Ovalau) the 2 nd group of people to inhabit this area. The first clan to inhabit the island was the people in Uluibau - they arrived from the sunken village out by the reef on the west side of the island. The outcrop on top of the ridge is supposed to symbolize a man (old?). A large heap of big sea shells were placed to the east of the rock as offerings to Paula. In the past the heap was larger but over time people have removed shells to make blow horns or shell trumpets. (The shells consist of triton, Cassie shells [Cypraecassis rufa], and Tridacna clams.) Several ornamental shrubs such as croton were at one time planted there in honor of Paula. Our guide Siti prayed a tribute to Paula. He also claimed that any photographs with flash would burn Paula thus he asked him permission and forgiveness for allowing us to use a camera. To honor Paula, and with the suggestion and help from Siti, we each planted an ornamental plant similar to the other.

9. This is a usual practice. For an example of this approach used in Naqelelevu, see Sand et al. 2007.

10. Oral history in Moturiki is relatively rich. The population of approximately 700 people is distributed in nine modern villages. The population is divided into yavusa (tribes) and mataqalis (clans). A recurrent tale that was told to us by different informants deals with Vuniivilevu, a reef with a sunken village, Tamidri, outside Uluibau. Tabutabu, the chief of the ring-ditch village was king of the sunken village. Vatu island people were brought to be eaten by Tabutabu, and thus the gods destroyed the village. We were told that when one travels by boat, one always crosses the face of Mataitamidri, the sunken village.

11. The GPS receivers used were Trimble GEOXT in 2008 and Leica SR20 in 2010. DGPS measurements came from two reference stations: Applied Geoscience and Technology Division of the Secretariat of the Pacific Community (SOPAC) (http://www.sopac.org/index.php/gps-data) and Geoscience Australia Fiji, Lautoka Continuous GPS (http://www.ga.gov.au/earth-monitoring/ geodesy/gnss-networks/station-list-and-coordinates.html).

12. A useful tool for this task is the Landserf software (http://www.landserf.org/), designed for the topographical analysis of Digital Elevation Models (see an application in Murrieta 2012).

13. The appearance of pottery on both Leleuvia and Caqalai on the coral limestone uplifted platform, outside of the current sandy perimeter of the islands, means that pottery was only exposed at low tide, probably indicating the movement of sand on top of the coraline platform.

14. Regarding Batan Island: "The eruption itself presumably helped to fill in the bay, not just by direct ash deposition but also by the subsequent in-washing of huge amounts of ash from hinterland valleys and slopes" (Bellwood et al. 2003:149).

15. Botanical analysis should be carried out specifically to address this problem. Analysis of our samples conducted at the Archaeobotanical laboratory in the Institute of History, Center for the Humanities and Social Sciences, CSIC in Madrid has been negative. Flotation of soil samples and residues produced no macro remains; this may be attributed to preservation problems. A larger sampling should be carried out to obtain positive results. Analysis of charcoal samples is still in progress.

16. As further corroboration of the disturbance of the site, they note, "It is clear from the stratigraphy and the lack of internal consistency of radiocarbon dates in some pits that some reworking of material has taken place. This is most pronounced along the inland side of the Lapita beach ridge, where fluvial processes are most likely to have been responsible for mixing of various strata" (Nunn et al. 2007: 101).

17. "Some 17,160 potsherds were collected from Naitabale through undiscriminating surface collection and excavation. Of this total, 92 sherds ( 0.5 percent) were either dentate-stamped Lapita or Lapitaincised ware" (Nunn et al. $2007: 105)$. Authors performed temper analyses on these fragments (see above), but they do not mention any characteristics of the more than 17,000 fragments collected, which can therefore potentially correspond to other periods.

18. Most of the abundant pottery remains could in fact have originated in higher areas around Naitabale, in particular Korovatu and the hills in Sawaikede basin. The Sawaikede stream could also have washed pottery remains from further inland.

19. "Nor is the area particularly attractive for lowland agriculture, with coastal lowland being limited and groundwater often saline ... and the area of cultivable lowland around the Naitabale site would have been considerably smaller" (Nunn et al. 2007:100).

20. "We have delineated a sequence of occupation that charts the movement of the population from an initial beach occupation in Lapita times up onto the higher parts of the island where nearly the entire population lived until European contact when missionaries encouraged people to move back down to the beach area where nearly everyone lives today. We have demonstrated significant expansions in habitation and subsistence gardening on the raised parts of the island during the first and second millennium AD. This expansion extended into very rugged and difficult peripheral areas, in which living and working would have required great effort. This intensification suggests that there was a period of population and subsistence stress on the island, as there was elsewhere in New Caledonia at this time" (Lilley et al. 2012:41). 
21. Height was calculated through the ASTER GDEM. Height estimates for each site were given through ArcGIS, Spatial Analyst Tools/Extraction/ExtractValuesToPoints.

22. Nunn and colleagues proposed a different interpretation of the beach sand at the bottom layers of Pit $\mathrm{T} 1$, arguing that it is "part of the Lapita beach ridge, and the sand that forms its lower layers is that deposited by waves during storms" (Nunn et al. 2007:102).

\section{REFERENCES CITED}

Allen, M. S., W. R. Dickinson, And J. M. Huebert

2012 The anomaly of Marquesan ceramics: A fifty year retrospective. Journal of Pacific Archaeology 3 (1) : 90-104.

BEDFORD, S.

2006 The Pacific's earliest painted pottery: An added layer of intrigue to the Lapita debate and beyond. Antiquity 80 (309): 544-557.

Bellwood, P., J. Stevenson, A. Anderson, and E. Dizon

2003 Archaeological and palaeoenvironmental research in Batanes and Ilocos Norte provinces, Northern Philippines. Indo-Pacific Prehistory Association Bulletin 23:141-161.

BEST, S.

1984 Lakeba: The Prehistory of a Fijian Island. Thesis submitted for the degree of Doctor of Philosophy at the University of Auckland, New Zealand.

BIRKS, L.

1973 Archaeological Excavations at Sigatoka Dune Site, Fiji. Fiji Museum Bulletin 1. Suva: Fiji Museum.

Burley, D. V.

2002 Archaeology of the Sigatoka Sand Dunes National Park. Report on the 2000 Field Season. Suva: Fiji Museum.

Burley, D. V., AND W. R. Dickinson

2004 Late Lapita occupation and its ceramic assemblage at the Sigatoka Sand Dune site, Fiji, and their place in Oceanic prehistory. Archaeology in Oceania 39: 12-25.

Cochrane, E. E.

2009 The Evolutionary Archaeology of Ceramic Diversity in Ancient Fiji. British Archaeological Reports. Oxford: Archaeopress.

Cruz Berrocal, M., and S. Millerstrom

2013 The archaeology of rock art in Fiji: Evidence, methods and hypotheses. Archaeology in Oceania 48:154-165.

Cruz Berrocal, M., A. Uriarte González, S. Millerstrom, S. Consuegra Rodríguez, J. Pérez-

Arias, S. Ormeño, and M. Conkey

2011 Archaeology in Moturiki, Lomaiviti Group, Fiji Islands. 2011 International Symposium on Oceanic Environment and Culture of the Matsu Archipelago, Taiwan: 255-263. Matsu, Taiwan: Cultural Affairs Office.

Dickinson, W. R., B. V. Rolett, Y. H. Sinoto, M. E. Rosenthal, and R. Shutler Jr.

1998 Temper sands in exotic Marquesan pottery and the significance of their Fijian origin. Journal de la Société des Océanistes 107:119-133.

FIELD, J.

2004 Environmental and climatic considerations: A hypothesis for conflict and the emergence of social complexity in Fijian prehistory. Journal of Anthropological Archaeology 23:79-99.

Frost, E.

1979 Fiji, in The Prehistory of Polynesia: 61-81, ed. J. D. Jennings. Cambridge, MA: Harvard University Press.

GLEndon, W. G.

2002 Particle size analysis, in Methods of Soil Analysis, Part 4: Physical Methods: 255-282, ed. J. H. Drane and G. Clark Topp. Madison: Soil Science Society of America Series 5.

GreEN, R.

1963 A suggested revision of the Fijian sequence. Journal of the Polynesian Society 72:235-253.

KIRCH, P. V.

1997 The Lapita Peoples, Ancestors of the Oceanic World. London: Blackwell Publisher. 
2000 On the Road of the Winds: An Archaeological History of the Pacific Islands Before European Contact. Berkeley: University of California Press.

JONES, S. R.

2009a Food and Gender in Fiji: Ethnoarchaeological Explorations. Lanham, MD, and New York: Lexington Books/Rowman and Littlefield.

$2009 b$ A long-term perspective on biodiversity and marine resource exploitation in Fijis Lau Group. Pacific Science 63 (4) : 617-648.

Lilley, I., Ch. Sand, and F. Valentin

2012 Collaborative research in New Caledonia. The SAA Archaeological Record September: 40-42.

Millerstrom, S., and M. Cruz Berrocal

2009 Fijian rock art sites revisited. Rapa Nui Journal 23 (1) : 40-47.

2010 Fijian rock art survey project 2009: A field report. Rapa Nui Journal 24 (1) :30-45.

Murrieta Flores, P.

2012 Entendiendo la movilidad humana mediante tecnologías espaciales: el papel de las áreas naturales de tránsito en el Suroeste de la Península Ibérica durante la Prehistoria Reciente. Trabajos de Prehistoria 69 (1) : 103-122.

Nunn, P., T. Ishimura, W. Dickinson, K. Katayama, F. Thomas, R. Kumar, S. Matararaba, J. Davidson, ANd T. WORThY

2007 The Lapita occupation at Naitabale, Moturiki Island, Central Fiji. Asian Perspectives 46 (1) : 96-132.

PARRY, J. T.

1997 The north coast of Viti Levu Bā to Rā: Air photo archaeology and ethnohistory. Bulletin of the Fiji Museum 10. Suva: Fiji Museum.

Petchey, F., M. Spriggs, F. Leach, M. Seed, Ch. Sand, M. Pietrusewsky, and K. Anderson

2011 Testing the human factor: Radiocarbon dating the first peoples of the South Pacific. Journal of Archaeological Science 38:29-44.

SAHLins, M.

2004 Apologies to Thucydides: Understanding History as Culture and Vice Versa. Chicago: University of Chicago Press.

SAND, CH.

1996a Archaeological structures, socio-political complexity and population density: New insight into the prehistory of the New Caledonian Archipelago, in Oceanic Culture History: Essays in Honour of Roger Green: 287-295, ed. J. Davidson, G. Irwin, F. Leach, A. Pawley, and D. Brown. New Zealand Journal of Archaeological Special Publication. Dunedin: New Zealand Journal of Archaeology.

$1996 b$ Structural remains as markers of complex societies in southern Melanesia during prehistory. The case of the monumental forts of Mare Island (New Caledonia). Bulletin of the Indo-Pacific Prehistory Association 15 (2):37-44.

Sand, Ch., F. Valentin, J. Bolé, A. Ouetcho, D. Baret, T. Sorovi-Vunidilo, and S. Matararaba

2007 Report and preliminary analysis of the first archaeological survey of Naqelelevu Atoll, Northeast Fiji. The Journal of the Polynesian Society 116 (4) : 407-432.

SHAw, E.

1967 A reanalysis of pottery from Navatu and Vuda, Fiji. M.A. thesis. University of Auckland.

\section{ABSTRACT}

Moturiki is one of the high islands in the Lomaiviti Group, central Fiji. In this article we present exhaustive empirical information on archaeological survey and test pit excavations carried out in 2008 and 2010. An interesting archaeological landscape emerged, with 89 archaeological sites found on Moturiki and neighboring islands Yanuca Levu, Leleuvia, and Caqalai. The sites include ring-ditch villages, terraced villages, isolated house mounds (yavus), and burial sites. Results from one of the test pits on the southeast of the island indicate possible landscape changes in the last millennium, since the ancient coastline is currently buried at around $1 \mathrm{~m}$ below the surface. This lowland area has therefore received large amounts of sediment from higher areas, a likely result of human 
activity. We also documented remains from a previously recorded Lapita site in the island. Overall, a shift in the settlement patterns from the coast, to the interior areas, back to the coast, has been documented. This shift, taking place on extremely small islands, can hardly be explained by environmental changes. The article puts together our findings and hypothesis, as well as providing the emphasis of our methodological approach. KeYwords: Fiji, Moturiki, landscape archaeology, archaeological survey, settlement patterns. 